\title{
Late Mississippian limestone sedimentary environment in southern Pembrokeshire (Bullslaughter Bay, Wales): evidence of meteoric diagenesis and hypersaline features
}

\author{
Yvonne Battiau-Queney ${ }^{1}$, Alain Préat $^{2}$, Alain Trentesaux ${ }^{1}$, Philippe Recourt $^{1}$ and Viviane Bout- \\ Roumazeilles $^{1}$
}

'Université de Lille, CNRS, Université Littoral Côte d'Opale, UMR 8187, LOG, Laboratoire d'Océanologie et de Géosciences, F-59000 Lille, France and ${ }_{2}$ Université Libre de Bruxelles, Research Group ‘Biogeochemistry \& Modelling of the Earth System', B-1050, Brussels, Belgium

\begin{abstract}
Bullslaughter Bay in southern Pembrokeshire, UK, exposes sections of Upper Mississippian limestone strata. In many places, the rock suffered an isovolumetric alteration during a period of sea-level oscillations. We used multiple approaches to study the weathered rocks, combining sedimentological, petrographic and isotopic compositions $\left(\delta_{18} \mathrm{O}\right.$ and $\delta_{13} \mathrm{C}$ values). Two main microfacies are recognized: (i) packstones/grainstones, characteristic of an open marine shallow subtidal/intertidal environment, with a high degree of agitation, slightly elevated salinity and temporary subaerial exposure; and (ii) mudstones/wackestones in a lagoonal setting and intertidal or supratidal environments, with a pedogenetic influence. In both cases, a complex diagenetic story, which started early in a meteoric environment, induced a strong alteration producing loose sediments in place of the parent rock. Calcretization, at or near the sediment surface in the vadose zone, was one of the most widespread diagenetic modes. It could be associated with beachrocks. Carbon and oxygen stable isotope analyses from more or less weathered limestones support the petrographic data: they show non-marine values with $\delta_{13} \mathrm{C}$ ranges of from $-2.13 \%$ to $1.75 \%$ and $\delta 18 \mathrm{O}$ from $-6.05 \%$ to $-4.66 \%$. These values are systematically lower than those of the middle Carboniferous seawater. Some periods of low sea level and subaerial exposure allowed gypsum to form. Neoformation of euhedral quartz by probable replacement after sulfate, and halite pseudomorphs after gypsum in a hypersaline environment are documented for the first time in southern Pembrokeshire. The studied weathered limestones present a complex diagenetic evolution related to sea-level oscillations in a range of hot and contrasting seasonal climates.
\end{abstract}

\section{Introduction}

The Middle and Upper Mississippian of southern Pembrokeshire has long been a subject of study for different reasons: lithology, stratigraphy, sedimentary facies, tectonics and the existence of remarkable breccias linked to the Visean limestones (Dixon, 1921; George, 1958, 1970, 1974, 1979; Thomas, 1971; Kelling, 1974; Owen, 1974; Jones, 1974; Leeder, 1992; Dunning, 1992; Kelling \& Collinson, 1992; Walsh et al. 2008). Waters et al. (2009) have recently given a synthesis of the lithostratigraphy of the Carboniferous successions of southern Britain. They used the international chart and not the historical nomenclature based on lithofacies. The same choice is made in this paper (Fig. 1). Recently, a particular type of isovolumetric weathered rock ('ghostrock' in Quinif, 2010) has been described in the Carboniferous limestones of southern Pembrokeshire (Rowberry et al. 2014). These formations are well observed in Bullslaughter Bay.

The purpose of our research was to explain the weathering processes. After five years of field campaigns and 
a set of various laboratory analyses, we are able to present new data on the Late Mississippian environment that propose a complex sequence of events. Sedimentological, petrographic and isotopic (carbon and oxygen) analyses of the Visean limestones of Bullslaughter Bay give evidence of multiple effects of sea-level oscillations on the depositional environment and early weathering of carbonate rocks.

\section{Geological setting}

The Mississippian sedimentary environment depended on local and regional contexts but also on global climate and eustatic sea-level changes. In southern Britain, and especially in South Wales, regional correlations between different formations are not easy because sedimentary successions frequently evolved in isolation, especially in late Visean and early Serpukhovian times (Waters et al. 2009). The Visean carbonate platforms of southern England and Wales evolved from gently sloping ramps in Asbian time to flat-topped shelves in Brigantian time (D. I. Gray, unpub. Ph.D. thesis, Univ. Newcastle upon Tyne, 1981; Walkden, 1987). The depositional environment in southern Pembrokeshire was that of a carbonate platform in a coastal or nearshore position. It was flanked to the south by a steep continental slope, and northwards it abutted the continental area known as St George's Land, which extended westward from the London-Brabant Massif.
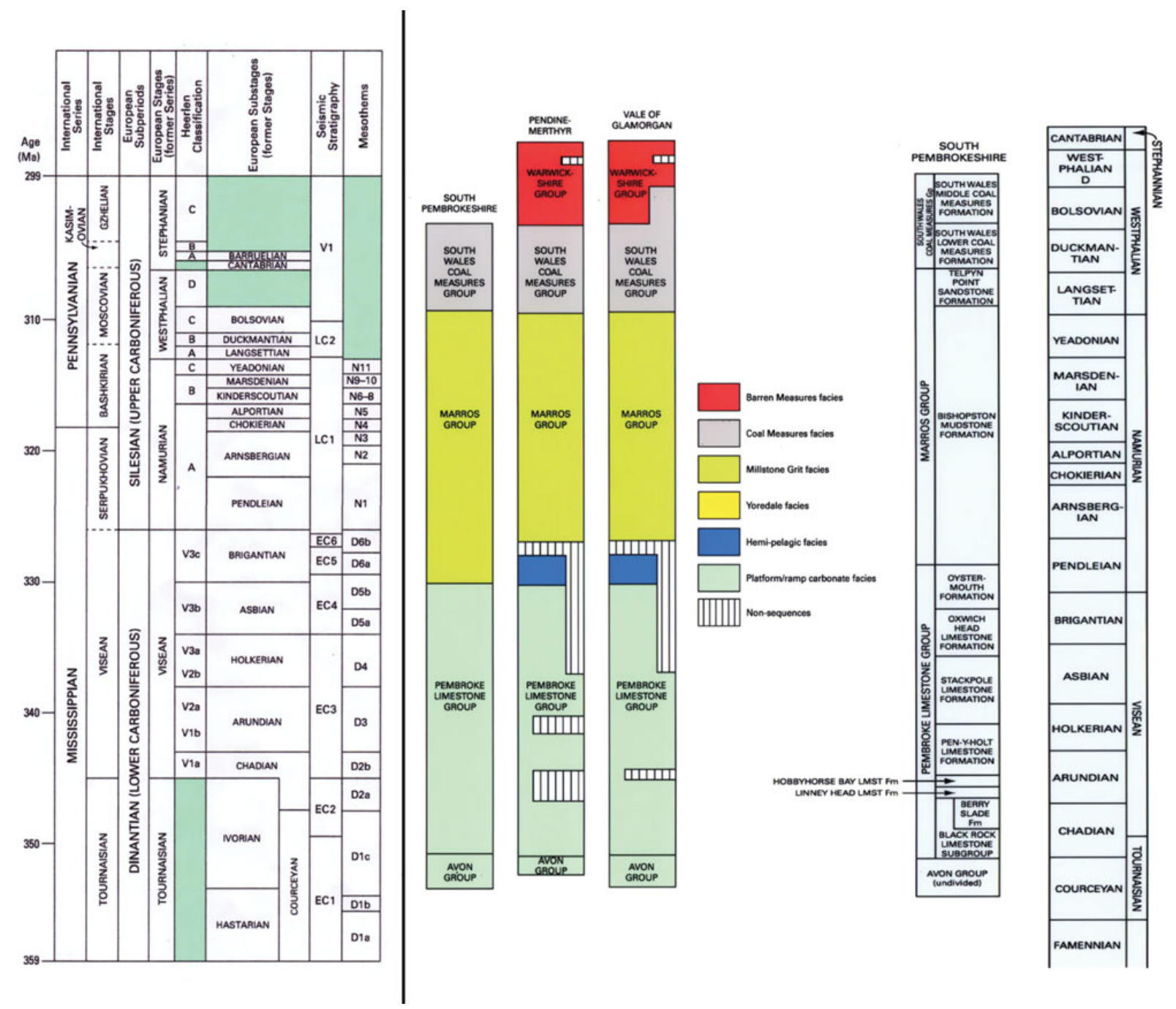

Fig. 1. (Colour online) Chronostratigraphic framework for the Carboniferous successions and southern Pembrokeshire groups and formations (source: Waters et al. 2009).

The sedimentation was cyclothemic and reflected sea-level oscillations driven by glaciation on Gondwana (Wanless \& 
Shepard, 1936; Ramsbottom, 1973, 1977; Davies, 1984; Horbury, 1989; Isbell et al. 2003; Davies, 2008 ; Rygel et al. 2008; Fielding et al. 2008). The emergence and submergence of the carbonate platforms began abruptly at around 330 Ma with an approximate periodicity of 100 ka linked to Milankovi'c eccentricity effects (Wright \& Vanstone, 2001). In southern Britain, the thickness of individual cyclothems increased from a few metres during Asbian time to as much as 30m during Brigantian time (Walkden, 1987), while eustatic sea-level oscillations increased from 10 to $50 \mathrm{~m}$ in Asbian-early Brigantian times to a maximum of $95 \mathrm{~m}$ by the close of the Visean period (Smith \& Read, 2000; Wright \& Vanstone, 2001). Each cyclothem started with subtidal sediments and was bounded at the top by exposure surfaces associated with palaeokarstic features, rhizocretions, laminar calcretes and clay palaeosols (Walkden, 1972, 1974; Somerville, 1979; Wright, 1982a; Walkden \& Davies, 1983; Davies, 1991; Wright et al. 1997; Vanstone, 1998). Glacial lowstands were characterized by a regular transition from humid to semi-arid climatic conditions (Vanstone, 1996, 1998). Well-preserved gymnosperm wood has growth rings indicative of tropical seasonality (Falcon-Lang, 1999).

As with other Asbian strata in southern Britain, the Oxwich Head Formation of southern Pembrokeshire hosts a range of surface exposure phenomena such as palaeosols near St Govan's Head (George, 2008) and palaeokarstic pits near Stack Rocks and Stackpole Head (Rowberry et al. 2014). Nevertheless, evidence of surface exposure phenomena had never been described in the Oxwich Head and Oystermouth formations of Bullslaughter Bay before the present study.

The South Wales Serpukhovian sequence (Lower Namurian in the old nomenclature) reflects the rapid southward development of a paralic-facies complex, fringing the uplifted St George's Land massif (Kelling, 1974; Kelling \& Collinson, 1992). Sea-level oscillations driven by the development of amajor ice-sheet in the southern hemisphere continued to characterize the period (Ramsbottom, 1977; Waters \& Davies, 2006). During Westphalian time, paralic or deltaic environments persisted in South Wales, which was 'marked by a low relief in which even minor adjustments of the relative sea level resulted in substantial lateral migration of the strandline and associated facies deltas' (Kelling, 1974). In Pembrokeshire, the Westphalian crops out in a thin belt extending from Carmarthen Bay to St Brides Bay. The Westphalian is totally absent southwards in the Castlemartin Peninsula and was probably never deposited. The Westphalian marks the onset of Variscan deformation with considerable changes in the regional topography of southern Pembrokeshire (Battiau-Queney, 1984). As a major consequence, St George's Land was peneplanated, and an uplifted land emerged in the Bristol Channel (Kelling, 1974).

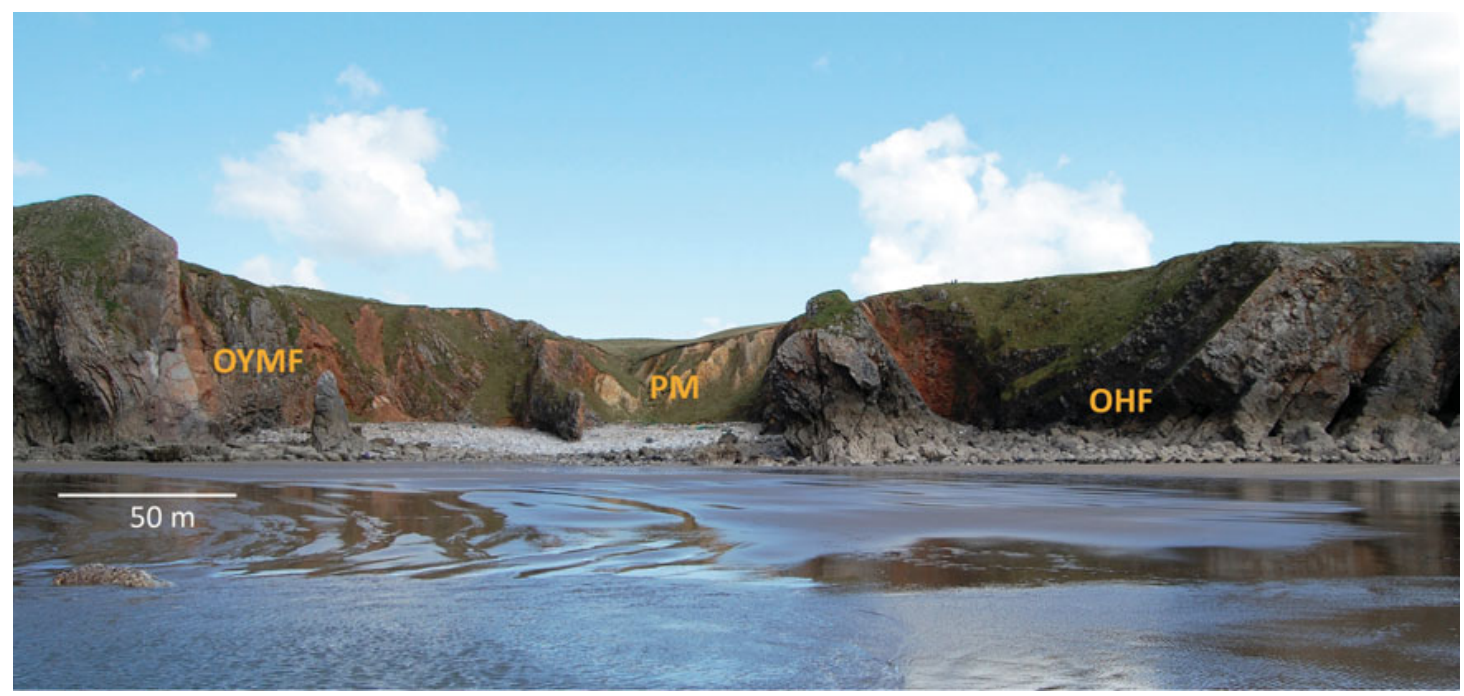

Fig. 2. (Colour online) Northward view of Bullslaughter Bay showing the Variscan folded limestone strata. In the middle, the yellowish rock marks the axis of the Bullslaughter Bay syncline. OHF - Oxwich Head Formation; OYMF - Oystermouth Formation; PM - Pendleian mudstones. 


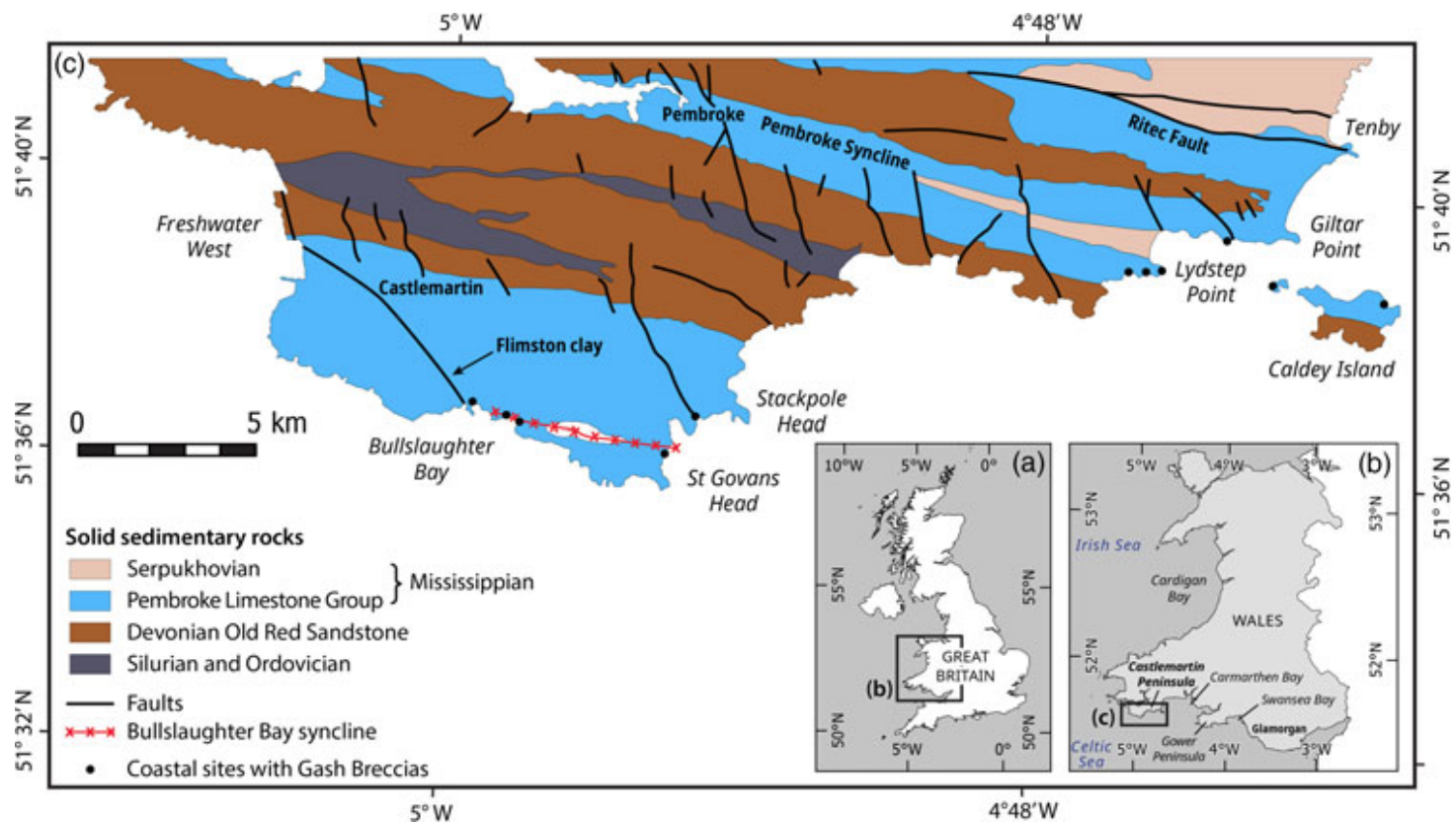

Fig. 3. (Colour online) Simplified geological map of southern Pembrokeshire. (Sources: Thomas, 1971; British Geological Survey, 1977; Walsh et al. 2008; design: D. Marin.)

\section{Study area}

Bullslaughter Bay is located on the south coast of the Castlemartin Peninsula within an 'Area of Outstanding Natural Beauty' in the Pembrokeshire Coast National Park (Fig. 2). The $250 \mathrm{~m}$ wide bay is surrounded by subvertical $35-40 \mathrm{~m}$ high cliffs by the edge of a flat plateau lying at 35-50m above sea level. The plateau truncates the Visean (Pembroke Limestone Group) and Serpukhovian folded strata (Fig. 3).

Two limestone formations are exposed in the cliffs of Bullslaughter Bay (Fig. 2): (i) the Oxwich Head Formation with thick-bedded recrystallized and bioturbated skeletal packstones/grainstones deposited during Asbian time; and (ii) the Oystermouth Formation with thin- to medium-bedded bioclastic grainstones, argillaceous limestones and mudstones deposited during Brigantian time (George et al. 1976).

Besides the general lithological characteristics of these Visean limestones, Bullslaughter Bay is known to host huge masses of breccias (Dixon, 1921; Thomas, 1971; Walsh et al. 2008; Woodcock et al. 2014). Less known and not yet studied is the presence in many places of yellow, red or black loose formations which contrast with the white/grey solid limestone. They form a heterogeneous patchwork with the parent rock and are sometimes laminated, especially in the first and second coves of the bay (Fig. 4). The properties and origin of these loose formations are the main topic of the present paper.

\section{Material and methods}

One hundred and fifty samples were analysed from both formations in the Laboratory of Oceanology and Geosciences of the University of Lille (France), using a range of techniques including calcimetry, particle size distribution, scanning electron microscopy (SEM) analysis, thin-section petrography, X-ray diffraction (XRD) and Raman spectroscopy of selected particles. The carbonate-content analyses were performed using a Bernard Calcimeter. X-ray diffraction was performed with a Bruker Endeavor DA system. Particle size distribution (PSD) was obtained by a Malvern Mastersizer 2000 laser diffraction instrument. The thinly laminated sediments were analysed using the sieve method. The samples were separated in sieves of three different sizes $(>200 \mu \mathrm{m}$, between 200 and $125 \mu \mathrm{m}$, and between 125 and $40 \mu \mathrm{m}$ ) to identify the grains and select some of them to obtain SEM micrographs and conduct energy-dispersive X-ray spectroscopy (EDX) analyses using an Environmental FEI Quanta 200 SEM coupled with a Bruker Quantax EDXS spectrometer. The exoscopy of 50 quartz grains was performed at Charles University (Czech 
Republic). Grains between 250 and $500 \mu$ mwere boiled for 10 minutes in concentrated hydrochloric acid, washed in distilled water and dried. They were subsequently mounted on carbon tape gold plated and photographed using a scanning electron microscope (JEOL 6380 LV).

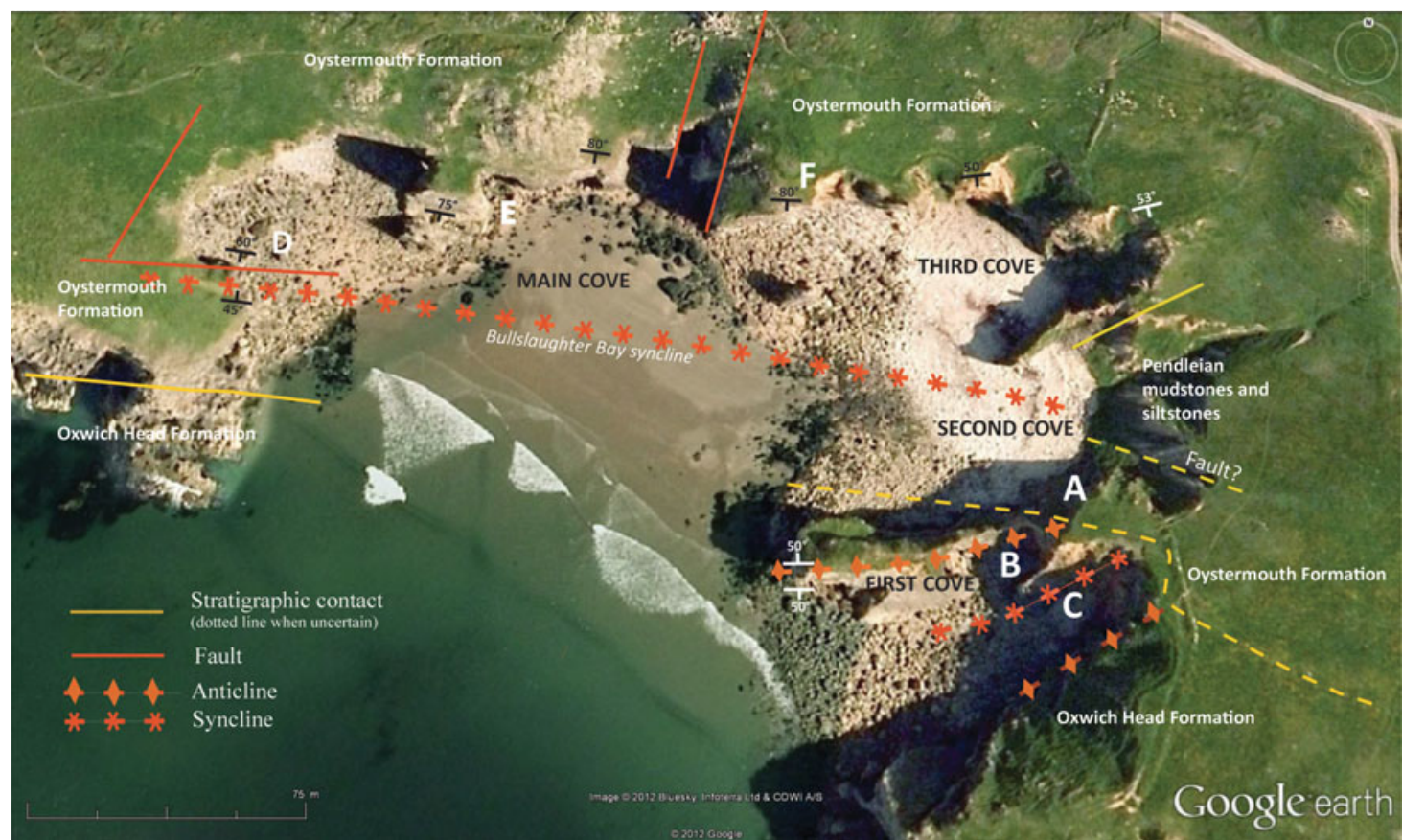

Fig. 4. (Colour online) Geological sketch of Bullslaughter Bay showing the main significant structures. The Oxwich Head Formation crops out on the west side of the bay south of the Bullslaughter Bay Syncline, and also on the southeast side. 'Gash-Breccias' are not indicated. A, B, C, D, E and F mark the sampling sites. (Sources: Dixon, 1921; Thomas, 1971; background from Google Earth (C) 2012 Bluesky, Infoterra Ltd \& COWI A/S.)

Thin-sections were made on more or less solid rocks and also on non-cohesive laminated sediments, which were impregnated. In the field the samples of non-cohesive material were pushed into rectangular $10 \times 7 \mathrm{~cm}$ boxes to keep the undisturbed structure of the sediment. Thin-sections were realized at the thin-section lab in Toul (France) and at the University of Lille (France). Micropetrography was performed with a BX60 microscope and a Flex camera. The mineralogy, particularly of iron oxides, was identified using a LabSpec HR800UV Raman microspectrometer (Jobin Yvon labs).

Thirty-two samples were selected for whole-rock carbon and oxygen isotopic analyses, in order to evaluate the effects of the diagenetic alteration as revealed through the petrographic study. They were prepared at the Free University of Brussels (Belgium). Analysed samples consisted of unaltered solid limestones and partly decalcified limestones. In one case (sample BB39) the altered carbonate and its parent limestone were analysed at their contact, at a centimetre scale.

Carbonate powders were reacted with $100 \%$ phosphoric acid at $70{ }^{\circ} \mathrm{C}$ using a Gasbench II connected to a ThermoFinnigan Five Plus mass spectrometer at the University of Erlangen- Nuremberg (Germany, Prof. M. Joachimski). All values are reported in per mil relative to the Vienna Pee-Dee Belemnite (V-PDB) by assigning $\delta^{13} \mathrm{C}$ and $\delta^{18} \mathrm{O}$ values of $+1.95 \%$ and $-2.20 \%$ to international standard NBS19 and $-46.6 \%$ and $-26.7 \%$ o to international standard LSVEC, respectively. Reproducibility and accuracy were monitored by replicate analysis of laboratory standards calibrated to NBS19 and LSVEC.

\section{Results}

\section{5.a. Lithostratigraphy}

The Visean formations consist of a diverse range of rock types including thin- to medium-bedded argillaceous mudstones-wackestones and thicker-bedded packstones and grainstones with brachiopods, echinoderms, 
foraminifers and algae. It is also common to encounter silicified limestones, chert nodules and cherty beds. Dixon (1921) noted frequent rapid lateral variations in the succession.

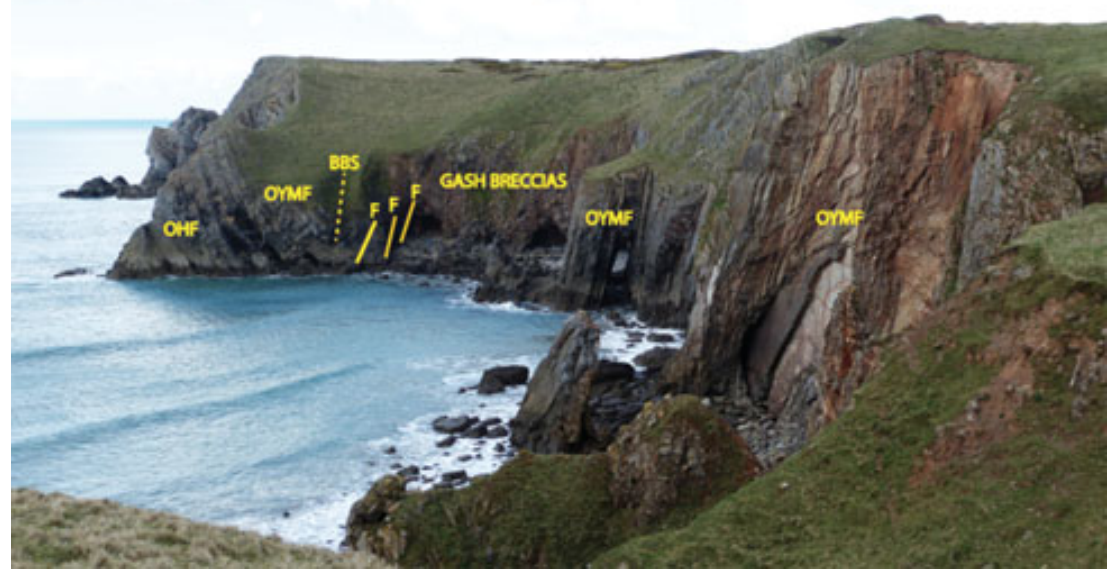

Fig. 5. (Colour online) Westward view of the western cliffs of Bullslaughter Bay. 'Gash-Breccias' separate the syncline axis and the near vertical limestones of the Oystermouth Formation. Small caves, dug by waves, expose good sections of the Oystermouth Formation with different rock types and rapid lateral or vertical facies. Several samples of the left cave (close to the fault zone) have been analysed (photo M. Rowberry, 2012). OHF - Oxwich Head Formation; OYMF - Oystermouth Formation; BBS - Bullslaughter Bay syncline.

On the west side of the bay (Fig. 5), the southern limb of the main syncline exposes medium-bedded limestones of the Oxwich Head and Oystermouth formations. The northern limb is faulted, and a huge mass of breccias (the so-called 'Gash- Breccias' of Dixon, 1921) replaces the original beds. Forty metres to the north, the cliff exposes nearly vertical thin-bedded limestones $(5-10 \mathrm{~cm}$ thick) of the Oystermouth Formation dipping southwards.

The eastern part of the bay exposes medium-bedded limestones (Fig. 6). According to Dixon (1921), they belong to the D2 Dibunophyllum Subzone, equivalent to the Oystermouth Formation, in site A, and to theD1 Dibunophyllum Subzone, equivalent to the Oxwich Bay Formation, in sites B and C. Nevertheless, Dixon noted that the contact between both formations is uncertain in the area, because of lack of zonal fossils of value, and also owing to the presence of breccias. In the second cove of Figure 4 (site A) a conodont assemblage was found in laminated sediments. They give a typical early Brigantian age (Błażejowski \& Walsh, 2013) and strengthen the attribution of these sediments to the Oystermouth Formation.

The Serpukhovian stage is poorly observed in the Castlemartin Peninsula and difficult to recognize with precision. In accordance with Dixon (1921), the British Geological Survey (1977) attributed to the Namurian an outcrop of black shales with cherts and brown fine-grained sandstones, close to the Newton farmyard, $1 \mathrm{~km}$ east of Bullslaughter Bay. Plant fragments were found but could not be determined (Dixon, 1921). A coastal deltaic or lagoonal sedimentary environment was suggested. The outcrop follows theW-E Bullslaughter Bay syncline (Fig. 3). In the eastern part of Bullslaughter Bay, in the main syncline axis, light yellowish siliceous mudstones with black cherts have been attributed to the same formation by Thomas (1971) who described them as 'downfaulted Millstone Grit shale', although the northern contact with the Oystermouth Formation does not seem clearly faultcontrolled. The southern limit cannot be seen properly in the field, but a fault zone is likely to exist at the contact with the limestones of the Oystermouth Formation exposed at site A. These mudstones are curiously indicated as Triassic Gash-Breccias on the geological map of the British Geological Survey (1996), although it is much more coherent and plausible to attribute them to the Pendleian (lower Serpukhovian). They are strongly weathered and folded. 


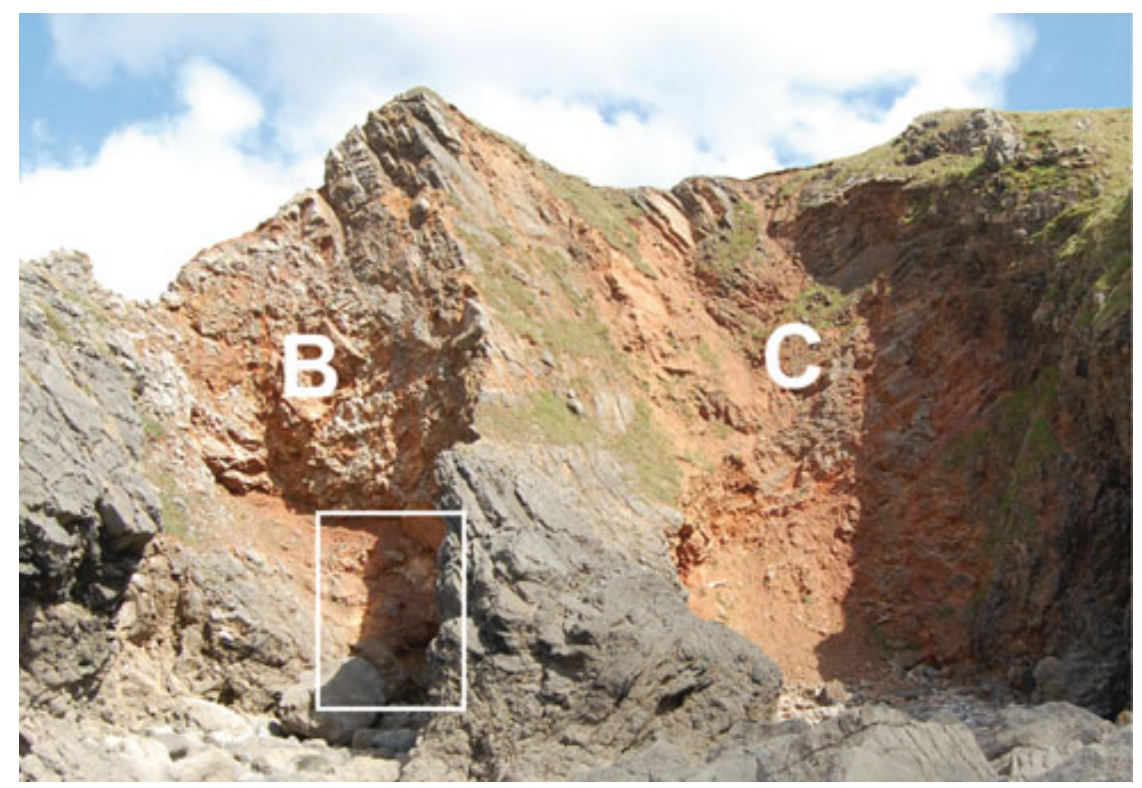

Fig. 6. (Colour online) The 'East Cove' of Figure 4 with sites B and C marked (view to the NE). The limestone belongs to the Oxwich Head Formation, according to Dixon (1921). A syncline axis sharply cuts site C. Placement of samples in the white frame. See detail on Figure 17.

\section{5.b. Structure}

The Variscan orogeny in South Wales began with preliminary movements through the Visean age (Owen, 1974). The late Visean unrest was widespread. In eastern Bullslaughter Bay it is evidenced by slight angular unconformities in the Brigantian sequence (see Fig. 16 below). Nevertheless, the main movements took place in late Stephanian - early Permian times (Leveridge \& Hartley, 2006). In southern Pembrokeshire, as in Gower and Glamorgan, Variscan structures are typically E-Wtrending. In the Castlemartin Peninsula, the Visean limestone beds have been strongly folded and rarely dip less than $45^{\circ}$. The fold axes are displaced by several SSW-NNE-trending cross-faults. The main regionally significant tectonic feature is theW-E Bullslaughter Bay syncline, which coincides with a fault zone in the western part of the bay. In the eastern part of the bay, the structure is very complex with a series of tight WSW-ENE-trending anticlines and synclines south of the main syncline axis.

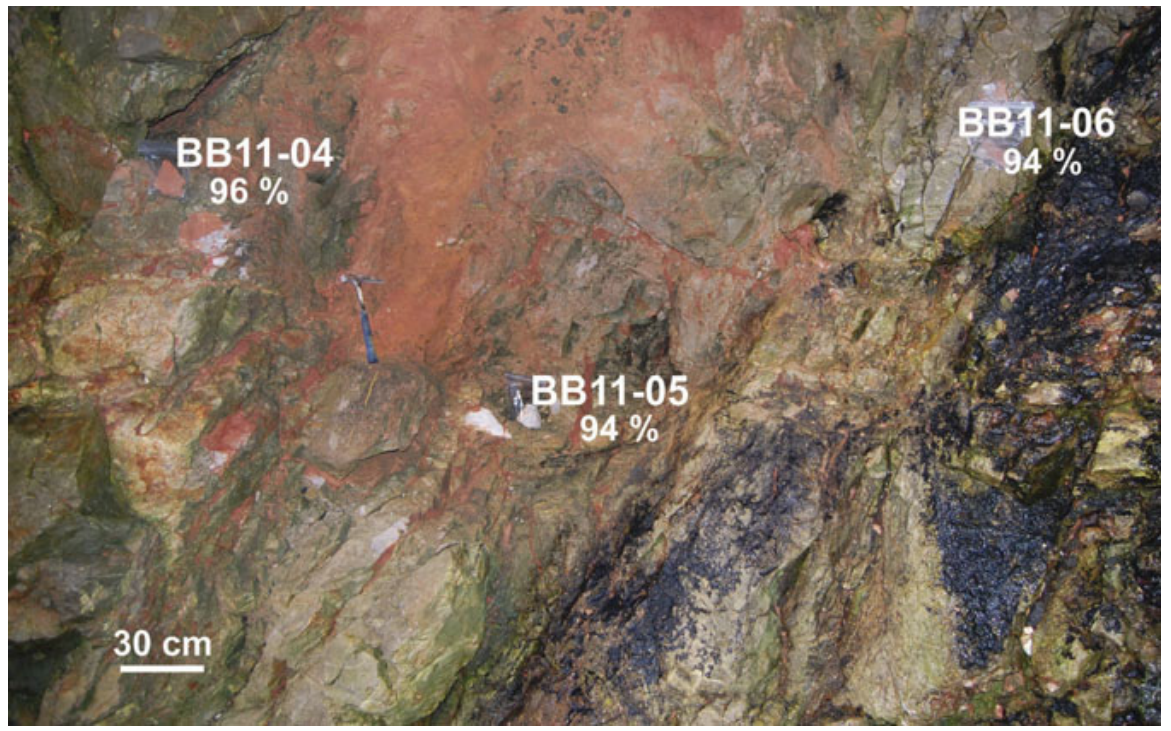

Fig. 7. (Colour online) Mosaic of solid and more or less weathered limestone at site D. For each sample the percentage of calcium carbonate is given (see also Table 1).

\section{5.c. Sedimentary facies}

The field observations of weathered rocks show two main facies, mosaic and laminated. 


\section{5.c.1. Mosaic facies of weathered limestone}

Weathered rocks are present in all places in the cliffs of the bay. The alteration rate changes rapidly from place to place giving a mosaic facies with a patchwork of strongly, weakly and unweathered rocks. It is particularly well seen on the northern side of the Bullslaughter Bay syncline, at site D. The patches of weathered rock are a few decimetres thick and may incorporate residues of the parent limestones (Fig. 7). Owing to the differential alteration, the facies can appear brecciated-conglomeratic with various sized and coloured blocks of host limestones embedded in a loose porous matrix (Fig. 8). The residual limestone blocks can form irregular discontinuous but bedding-concordant lenticular sheets.

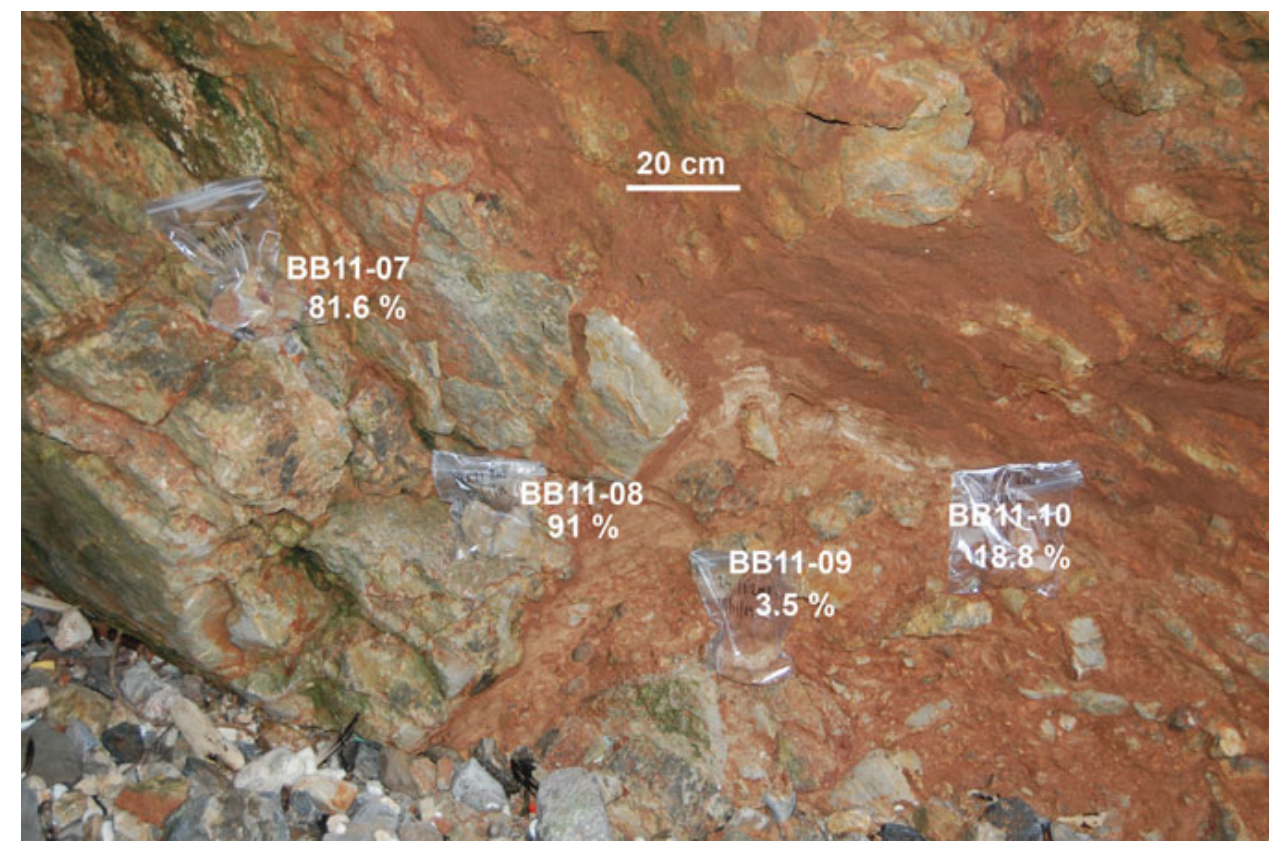

Fig. 8. (Colour online) More or less weathered limestone at site D with slight laminated structure of the reddish loose material (see also Table 1).

In several places, it is possible to see the gradual transition from the solid to weathered rock, proving that nothing was significantly displaced during the alteration process. Weathered rocks can be seen in sheltered places having no connection with the present topographic surface. In two places, the weathered rocks have been found in small natural caves embedded in the solid rocks: the first one in a few metres wide cave of site D on the western side of the bay (seen on Fig. 5, below ' $G$ ' of the Gash-Breccias) and the other one in a metre-scale cavity at the base of site B (Fig. 6 and 'a' in Fig. 17 below). More generally, although the alteration rate may change rapidly, it is not related to a vertical gradient linked to the present topography but rather to the bedding planes. Carbonate-content analyses of several samples of solid and more or less weathered rocks reveal a close relationship between the rate of weathering and the loss of calcium and rock density (tested in the field with a Schmidt hammer) (Figs 7, 8; Table 1). This type of weathered limestone is similar to the 'ghost-rock' defined by Quinif (2010). It occupies the same space as the solid rock but it is more or less crumbly and easily crushed into silt and fine sand. The related loss of calcium of this 'ghostrock' has been reported in the studied area by Rowberry et al. (2014). Solid limestone rocks are more than $94 \%$ $\mathrm{CaCO} 3$; weakly weathered limestones, which are still relatively hard, display CaCO3 values of between $91 \%$ and 94 $\%$; moderately to deeply weathered rocks, which easily crumble, contain between $81 \%$ and $3.5 \%$ CaCO3 (Table 1 ). 
Table 1. Carbonate content of several samples of sites A, B and D (see text for explanation)

\begin{tabular}{|c|c|c|c|c|}
\hline Site & Sample number & $\mathrm{CaCO} \%$ & Type of material & Facies \\
\hline A & BB5 & $11 \%$ & Red silty laminae & $\mathrm{L}$ \\
\hline$A$ & 1512 & $64 \%$ & Yellowish crumbly laminae & L \\
\hline A & 1529 & $76 \%$ & Weathered limestone & $M / L$ \\
\hline B & BB34 & $>98 \%$ & Weakly weathered laminae & $\mathrm{S}$ \\
\hline B & BB37 & $>98 \%$ & Solid hard limestone & $S$ \\
\hline B & BB39 & $>98 \%$ & Weakly weathered limestone & $S$ \\
\hline B & BB40 & $>98 \%$ & Fragments of solid rock & $S$ \\
\hline B & BB43 & $>98 \%$ & Solid hard limestone & $S$ \\
\hline B & BB30 & $7.5 \%$ & Black loose laminae & $\bar{L}$ \\
\hline B & BB32 & $31 \%$ & Crumbly yellowish laminae & $\mathrm{L}$ \\
\hline B & BB33 & $61 \%$ & Yellowish/reddish silt & $\mathrm{L}$ \\
\hline B & BB35 & $33 \%$ & Crumbly bladdish laminae & $\mathrm{L}$ \\
\hline B & BB36 & $60 \%$ & Brownish sandy silt & L \\
\hline B & BB38 & $72 \%$ & Loose yellowish/reddish laminae & $\mathrm{L}$ \\
\hline B & 1550 & $4 \%$ & Loose black laminae & $\mathrm{L}$ \\
\hline B & 1552 & $20 \%$ & Loose blackish laminae & L \\
\hline B & 1553 & $4 \%$ & Reddish loose material (with akaganéite) & $\mathrm{L}$ \\
\hline B & BB40 & $45 \% 100 \%$ & Reddish loose material with small embedded solid fragments & L/MS \\
\hline B & BB41 & $21 \%$ & Thin black laminae & $\mathrm{L} / \mathrm{M}$ \\
\hline B & BB42 & $51 \%$ & Loose reddish material & $M / L$ \\
\hline B & BB44 & $7 \%$ & Silty material & $M / L$ \\
\hline $\mathrm{D}$ & BB11-04 & $96 \%$ & Weakly weathered limestone & $S$ \\
\hline $\mathrm{D}$ & BB11-05 & $94 \%$ & Weakly weathered limestone & $\mathrm{S}$ \\
\hline D & BB11-06 & $94 \%$ & Solid limestone & $\mathrm{S}$ \\
\hline $\mathrm{D}$ & BB11-08 & $91 \%$ & Weakly weathered limestone & $\mathrm{M}$ \\
\hline $\mathrm{D}$ & BB1 & $47 \%$ & Weathered limestone & $\mathrm{M}$ \\
\hline $\mathrm{D}$ & BB2 & $70 \%$ & Moderately weathered limestone & $\mathrm{M}$ \\
\hline $\mathrm{D}$ & BB11-03 & $87 \%$ & Weakly weathered limestone & M \\
\hline $\mathrm{D}$ & BB11-04 & $96 \%$ & Hard limestone & $\mathrm{S}$ \\
\hline $\mathrm{D}$ & BB11-05 & $94 \%$ & Weakly weathered limestone & $\mathrm{M}$ \\
\hline D & BB11-06 & $94 \%$ & Weakly weathered limestone & M \\
\hline $\mathrm{D}$ & BB11-07 & $81.6 \%$ & Moderately weathered limestone & $\mathrm{M}$ \\
\hline $\mathrm{D}$ & BB11-08 & $91 \%$ & Weakly weathered limestone & $\mathrm{M}$ \\
\hline $\mathrm{D}$ & BB11-09 & $3.5 \%$ & Loose material & $M$ \\
\hline $\mathrm{D}$ & BB11-10 & $19 \%$ & Weathered yellowish limestone & $M$ \\
\hline
\end{tabular}

\section{5.c.2. Loose laminated facies}

The loose laminated facies concern, in particular, the southern limb of the Bullslaughter Bay syncline, in the first and second coves of the bay, where the Oxwich Head and Oystermouth formations crop out (Fig. 4). Forty-five samples from sites A and B were analysed. Here, the laminated sediments contrast strongly with the host limestone with their yellow, red or grey colour, loose consistency, silty texture and poor $\mathrm{CaCO} 3$ content (4-72\% in Table 1).

They may incorporate solid or more or less weathered residues of the parent limestones. At site A, a spectacular formation - although not reported in detail by Dixon (1921) and ignored by Thomas (1971) - has aroused interest over the past 40 years (Battiau-Queney, 1980; Błażejowski \& Walsh, 2013; Woodcock et al. 2014) (Fig. 9). In fact, the origin of this formation was never made clear owing to the lack of analyses.

Although the studied area is just a few square metres, it provides interesting data to reconstruct the story of 
sedimentation. The thin- to medium-bedded parent limestone steeply dips northwards $\left(45^{\circ}\right.$ to $\left.50^{\circ}\right)$ (white arrows in Fig. 9). In Figure 10, a block of limestone (Fig. 10 'a') is locally laminated and weakly weathered. On the left side (Fig. 10 'b'), very thin millimetric curved laminae, made of silt and fine sand, abut on the block (see detail in Fig. 10). It could be an aeolian deposit. It has been truncated (Fig. 10 'c') by a $3 \mathrm{~cm}$ thick bed of coarser sand, which is roughly laminated and covered by a $1 \mathrm{~cm}$ thick fine sand bed. This bed is covered by a series of a few centimetres wide undulated beds showing imbricated superposition, which skirts the limestone block (Fig. 10 'd'). Masses of heterometric coarse sand, angular gravels and small blocks of transported weathered limestone lie on these beds, sometimes in centimetre-sized furrows (Fig. 10 'e'). To the right of the hammer in Figure 10 (Fig. 10 ' $\mathrm{f}$ '), there is the presence of an enterolithic-type structure with bulging or 'boudinage' (Fig. 10, detail). Fossils of the local parent rock are abundant in this heterometric material. The structural disposition of these sediments suggests a slope deposit in a metric-sized open cavity formed during a period of emergence, with evaporitictype sliding and slumping. Halite and gypsum have been discovered in these contorted laminae (see Section 5.d below, site A).

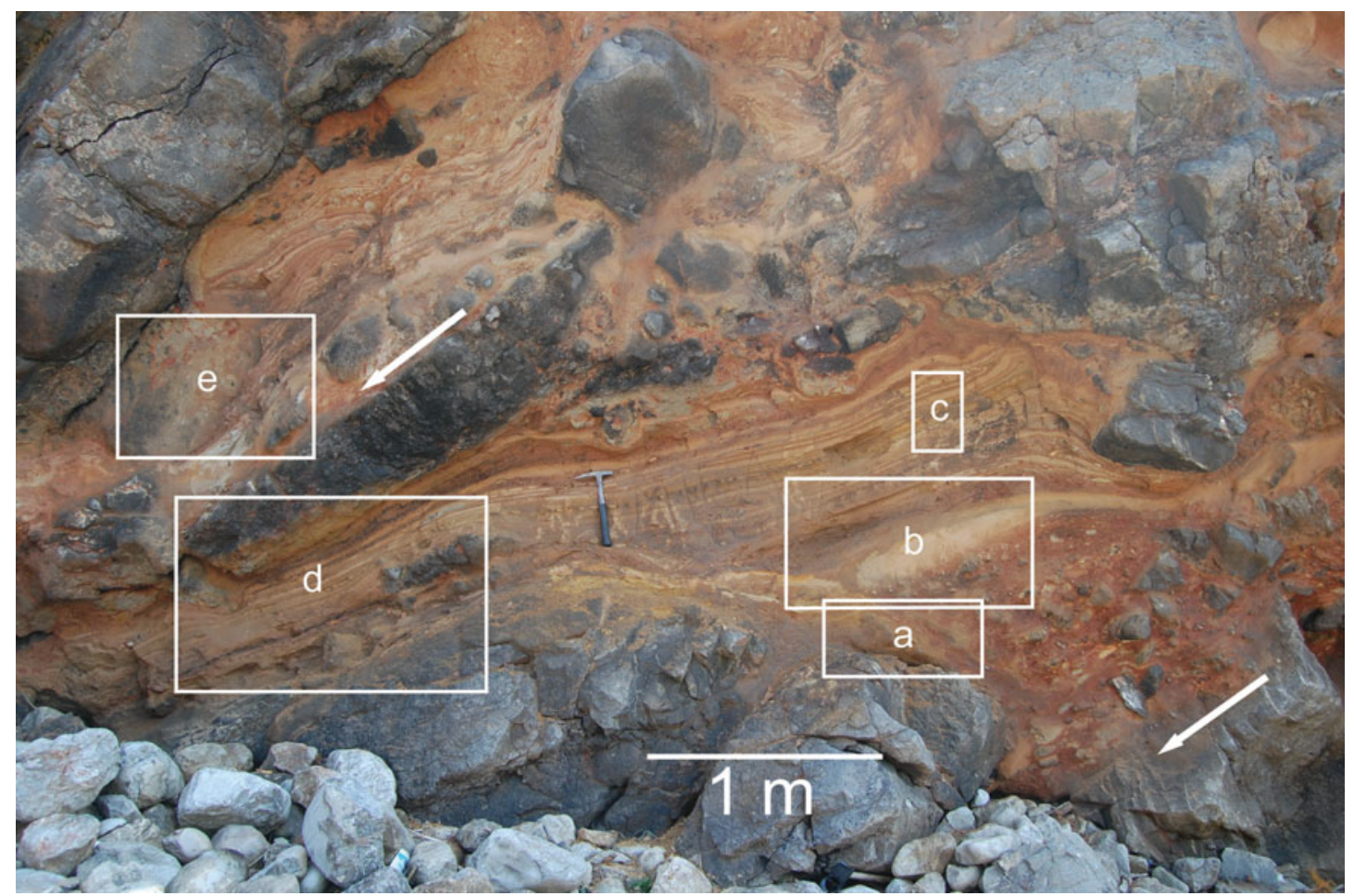

Fig. 9. (Colour online) Site A: general view with position of Figures 10-14.

They are overlain by a lenticular bed containing $54 \%$ silt and $36 \%$ fine sand (less than $125 \mu \mathrm{m}$ ) (sample BB11 in Fig. 11). On the left, curved laminae are present, but they disappear to the right. The mineralogy of this sample is described below. It passes upwards to a planar thinly laminated sediment (Fig. 12). The laminae are mainly composed of silt $(50-55 \%)$ and fine sand ( $\sim 35 \%)$. The finer ones contain $\sim 80-85 \%$ silt and 15-20\% clay. A few laminae are coarser (coarse sand and small gravel). Laminae are a few millimetres to $4 \mathrm{~cm}$ thick. The lamination is planar with upwards fining of the grain size. Synsedimentary microfaults (Fig. 12, white arrows) and flame structures are present. The same type of thin laminated sediment is observed in Figure 13, from which several samples were analysed (Section 5.d below).

In some places, the contact of the loose laminae with the solid rock seems relatively sharp. Locally, they wrap the parent limestone rock (Fig. 14).

In other cases, the lamination continues into the weathered rock (Fig. 15). Dixon (1921) already noted the 
presence of 'silty laminated limestones' in the Oystermouth Formation (D2 Dibunophyllum Subzone), which crops out here.
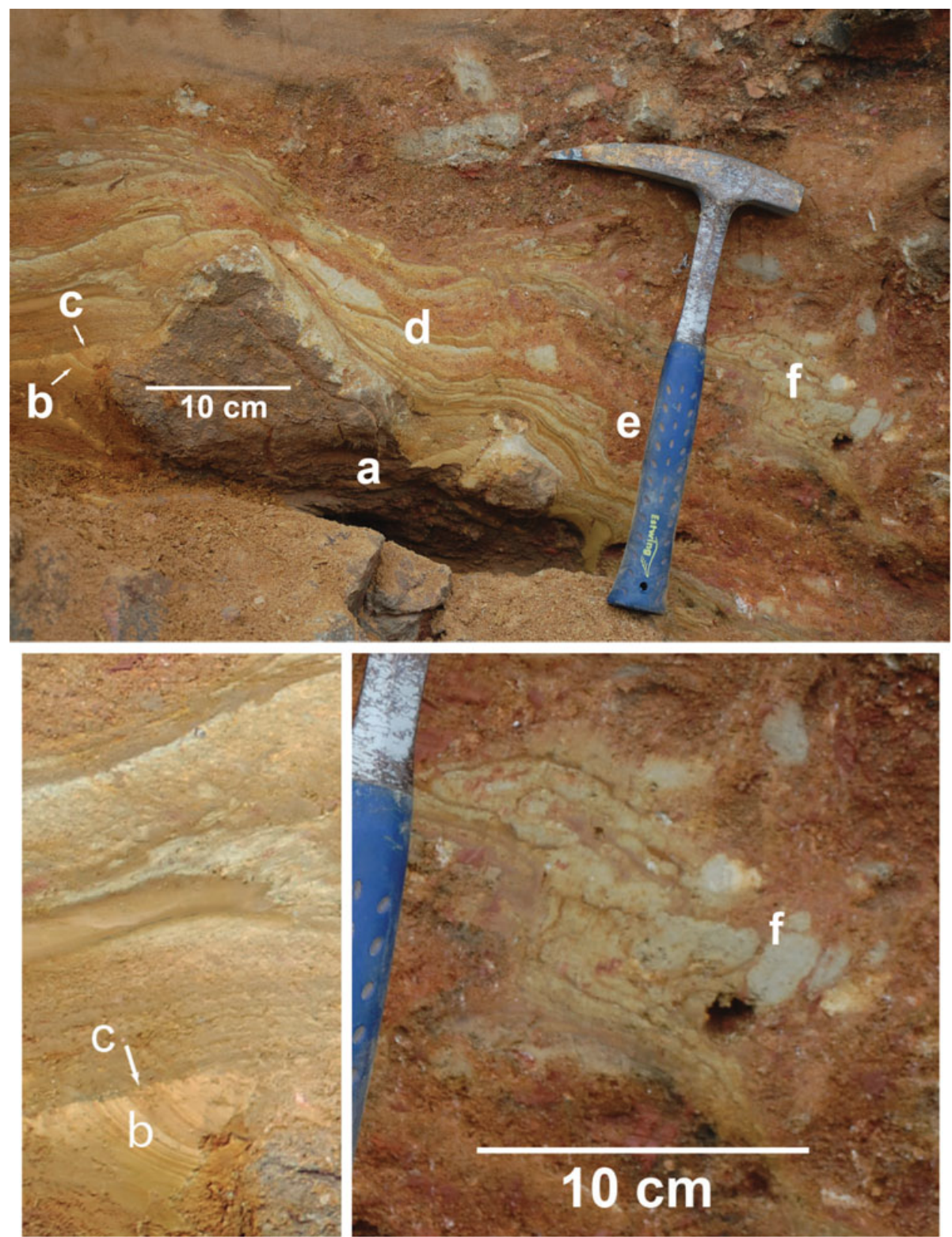

Fig. 10. (Colour online) Site A: laminated sediments (box 'a' of Fig. 9) with detailed pictures below

A picture showing the reconstructed setting in Brigantian time, before the Variscan folding (Fig. 16), helps to understand the disposition of the sediments. The area with weathered rock and laminae is $\sim 2 \mathrm{~m}$ thick (1.6 to $2.5 \mathrm{~m})$. It is covered in a slight angular unconformity (Fig. 16, dotted line) by a hard-grey limestone bed, which underlies reddish moderately weathered thinner limestone beds (sample 1528, see Section 5.d below, site A). The sediments, which have been identified as possible slope deposits with enterolithic-type structures (Fig. 16 'a') are nearly perpendicular to the underlying horizontal bed and wrap a $1 \mathrm{~m}$ high rocky slope (Fig. 16 'b'). The laminae (Fig. 16 'c') skirt the residual fragments of solid or moderately weathered parent rock. But they also pass gradually to laminated in situ rock (Fig. 15). Their structural arrangement favours the hypothesis of deposition in non-turbulent water on a rough rocky platform.

At site B (Fig. 17) several patches of laminated sediments have been discovered during the field survey. They have never been described before, probably because they were not visible when Dixon (1921) investigated the area. In 
fact, the active current slope processes can conceal or reveal some features at any time. Here the cliffs expose the Oxwich Head Formation (D1 Dibunophyllum Subzone of Dixon). The laminar units show similarities with those of site A, although planar graded thin laminae are less frequent (Figs 18-20). The structural continuity from solid to laminated rock is seen in several places (Figs 18, 19).

\section{5.d. Petrography and mineralogy}

To better understand the process of limestone alteration and the laminar depositional environment, petrographic (thinsections), mineralogical (XRD), chemical (calcimetry, Raman spectroscopy, EDX) and SEM analyses were carried out on several samples to complete the field observations.

Approximately 50 samples were taken for petrographic analysis from the limestones at the different sites of the bay. They consist of two main microfacies as follows:

Microfacies 1 or packstones/grainstones: this microfacies consists of poorly laminated echinodermal (crinoids, sea urchin spines) and bioclastic (algae, benthic foraminifers, bryozoans, pelecypods, brachiopods, ostracods) facies with micritized well-sorted oolites (Fig. 21a, b). Bioclasts and oolites are frequently cross-bedded with thin (millimetre to centimetre) low-angle laminae. A thin irregular lamellar calcitic cement followed by blocky and granular cements is observed between the micritized oolites. Pisolites (up to $2 \mathrm{~mm}$ ) and oncoids (up to $1 \mathrm{~mm}$ ) are observed in the grainstones and bordered by irregular calcitic meniscus cements (Fig. 21a, b). Most of the grains are coated by a dark micritic cortex leading to the formation of composite 'ooidic- oncoidic' grains. The distribution of the cements is heterogeneous (Fig. 21b). A peloidal fenestral fabric is commonly observed in the packstone facies. Fenestrae are mostly irregular or tubular, sometimes developing a laminoid fabric with gravitational cements on their tops (Fig. 21c-h). Cylindrical fenestrae with the long axes subparallel to the bedding is regularly observed (Fig. 21d). The largest fenestrae form centimetre-sized cavities with micrite relics bordered by at least two lamellar calcitic cements. Anastomosing cracks are commonly observed and associated with strong alteration

of the matrix and precipitation of a thin bladed calcite cement (Fig. 21g). The matrix of the packstone facies consists commonly of a fine-grained microsparite replacing totally or partly the primary facies. Silicification is sometimes observed.

Microfacies 2 or mudstones/wackestones: this microfacies contains a few bioclasts (mainly echinoderms) in a microsparitized micritic matrix containing large-sized irregular sparmicritized (Kahle, 1977) fenestral-like cavities connected to thin tubules or veins (Fig. 22a-f). The cavities in the micrite are lined by two replacive calcite cements, the first one being lamellar or bladed, the second one being blocky equant and sometimes centripetal (Fig. 22a-d). Microcodium clasts composed of prismatic grains are probably present (Fig. 22b). The matrix also contains smallsized pyrite and sometimes displays an alveolar structure sensu Wright (1982b). Small-sized dolomite rhombs are also observed. Sometimes they are abundant in site D. The matrix suffered in-place recrystallization and was partly replaced by large-sized yellowish calcitic crystals.

Microfacies 1 and 2 are present together at each study site (A, B and D). They are altered and lose their original characteristics, especially in sites A and B, which transforms the parent rocks into crumbly sediments in the loose laminated facies. In this case, it is often impossible to determine whether the original microfacies is type 1 or type 2, especially when the dissolution has been very extensive. In general, the processes of alteration are marked mainly by dissolution and/or cementation, micro- or macro-sparitization and ferruginization. They are analysed below on the basis of representative samples. 


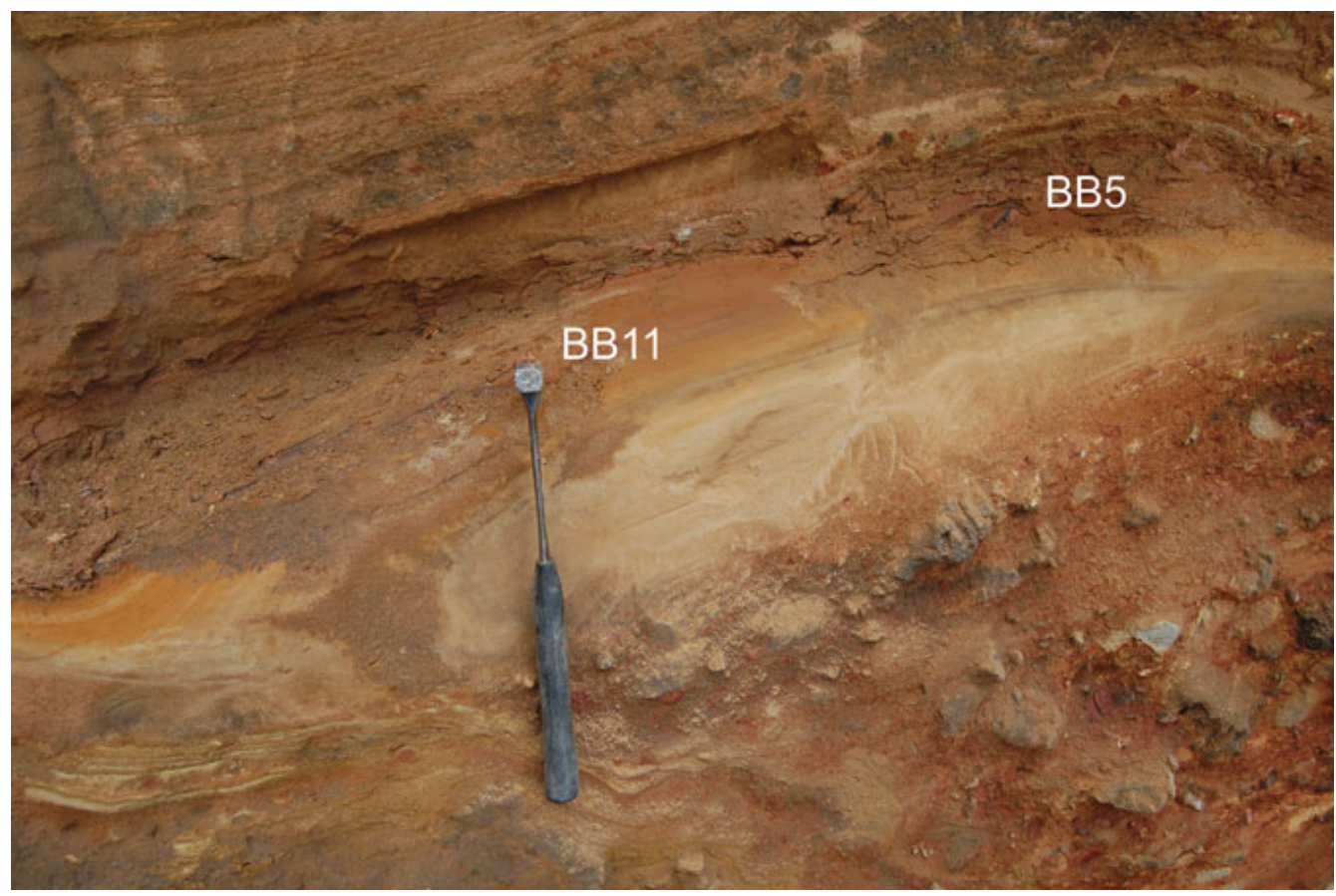

Fig. 11. (Colour online) Site A: contact of silty-sandy bed with laminated sediment (box 'b' of Fig. 9). Hammer for scale is $32 \mathrm{~cm}$ long.

At site A, sample BB5 from a red lamina (Fig. 11) has a PSD of82 \% silt (between $2 \mu$ mand $63 \mu \mathrm{m}$ ) and 15 $\%$ clay (less than $2 \mu \mathrm{m}$ ). The mineralogical composition of the total rock (XRD) is dominated by quartz and goethite with $11 \% \mathrm{CaCO} 3$ (Table 1). XRD analysis of the clay fraction gives $90 \%$ illite/muscovite. Sample BB11 taken from a yellowish lamina (Fig. 11) has a PSD of $54 \%$ silt and $36 \%$ fine sand (less than $125 \mu \mathrm{m}$ ) and a mineralogy dominated by calcite and quartz (XRD). Sample 1512 (Figs 13, 21) contains 64 \% CaCO3 (Table 1). A thin-section from this sample has been analysed in detail (Fig. 21). It consists of a well-developed fine- to medium-grained greyish dirty microsparitic matrix replacing partly or totally the bioclasts (molluscs, brachiopods, algae, bryozoans, foraminifers, echinoderms). Fenestrae, gravitational cements, calcified roots and shrinkage cracks have been observed. Peloids are common, sometimes very abundant, and associated with silty quartz grains coated by goethite (Raman spectroscopy). Columnar palissadic gypsum (sometimes pseudomorphed by calcite) are locally observed in silty and clayey mudstones (Figs 24, 25) They are associated with abundant small euhedral bipyramidal quartz crystals (Figs $24 \mathrm{~b}, 26)$. In the most-altered facies, replacement and ferruginization of the grains is common. Echinoderm fragments show dissolution vugs and are microsparitized or partly replaced by orange and brown clay aggregates. Sub-rounded to well-rounded reddish to blackish Fe-(Mn?) pisolites (up to several millimetres), with irregular asymmetric cement, are also observed (samples 1512, 1513; Fig. 13). Sample 1528 is microsparitized and contains abundant Fe-pisolites with a few preserved pelecypods in an irregular brownish laminar crust. Abundant gypsum patches forming hemi-pyramids and rosettes (Logan, 1987), up to $200 \mu \mathrm{m}$, grew in the sediment. Fractures, open and filled, are widespread, mostly between the pisolites.

In SEM, samples 1512 and 1513 contain abundant bipyramidal euhedral quartz, gypsum crystals and micas flakes (Fig. 24). The euhedral quartz grains are always characterized by a pitted surface and a vacuolar structure (Fig. 26). Their length rarely exceeds 50 to $80 \mu \mathrm{m}$. Most of them are smaller. They are found in all laminated formations of site A. In sample BB11, an aggregate of small bipyramidal quartz is mixed with micro-patches of residual gypsum (Fig. 24b).

Sample 1532, taken from a weathered laminated limestone, close to the loose laminae 1512, 1513 and 1514 (Fig. 13), contains abundant millimetric pristine crystals of fibrous material. Some of them are curved and look like ram's horn gypsum crystals. In SEM the chemical analysis shows that they are made of pure halite. In fact, they are 
halite pseudomorphs after gypsum (Fig. 27).

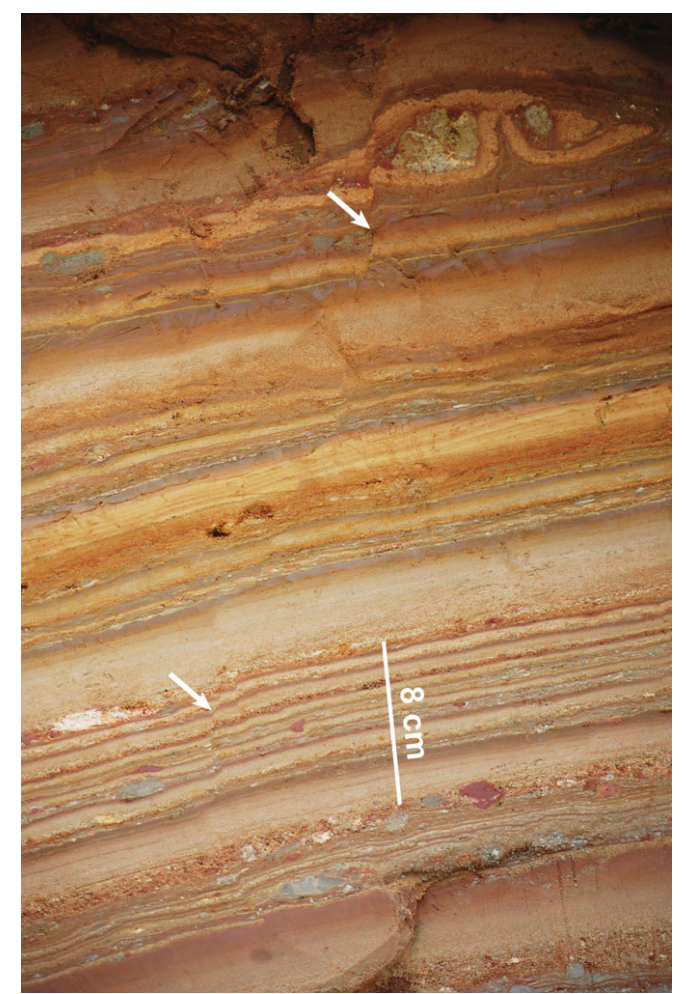

Fig. 12. (Colour online) Site A: graded planar laminae (box 'c' of Fig. 9).

At site B, several samples were analysed. Sample BB30 (Fig. 20 and Fig. 17 'd') corresponds to a black loose laminated material with small solid rock fragments. BB37 is a solid hard limestone. BB39 is a moderately weathered limestone, still cohesive but easily crumbled. Both are seen on Figure 17 ('d') and Figure 22. BB43 and BB44 were taken from a small cavity in a roughly laminated material (Fig. 17 'a'). BB43 is a weathered limestone with different grades of alteration (Fig. 21). BB44 is a loose sandy rock. BB7 and BB8 are well laminated. They are seen on Figures 18 and 17 ('b’).

The most-altered facies are related to the fine-grained mudstones/ wackestones and muddy packstones. They consist of a fine microsparitic mudstone with micritized grains and abundant irregular veins and small-sized cavities filled with coarse-grained calcite (sample BB39, Fig. 22a-d). The micritic coatings are sometimes thick and asymmetric (Fig. 22a). Their main characteristics are extensive microsparitization and the abundance of various calcitic cavities with medium- to coarse-grained sparry calcite interconnected or in association with a fracture pattern. Large calcitic deformed crystals embedded in the microsparitized matrix are common (Fig. 22c). Peloids are common, sometimes abundant and associated with silty quartz grains coated by iron oxides. In SEM, bipyramidal euhedral quartz with a vacuolar structure is present in all laminated facies and especially abundant in BB44, BB7 and BB8. Gypsum crystals are abundant in samples BB7 and BB8 (Fig. 25). In BB39, calcite crystals have replaced sulfates before being dissolved and silicified. The matrix also shows strongly deformed microsparitic veins, with multiplication of the primary thickness by folding or sliding and microslumps (sample 1521 in Fig. 18). 


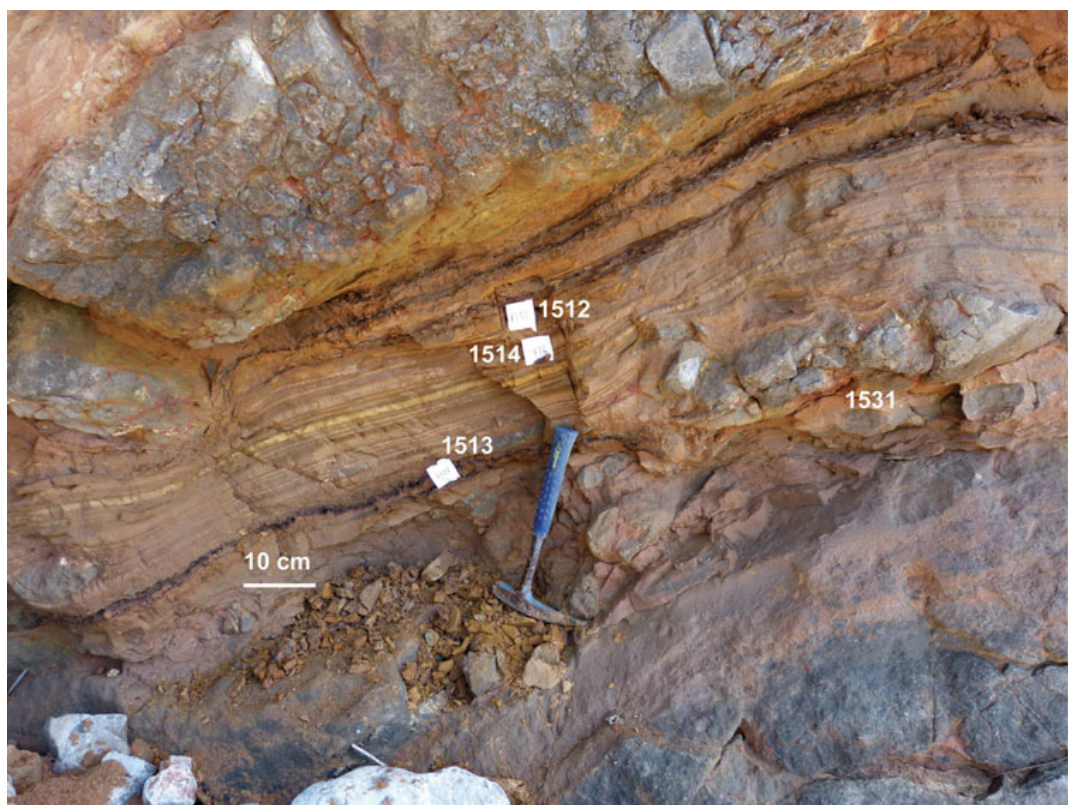

Fig. 13. (Colour online) Site A: graded laminae (box 'd' of Fig. 9), with position of samples.

Another characteristic of site B is the presence of laminae very rich in iron oxide, identified as goethite by XRD. Sample BB30 contains $7.5 \% \mathrm{CaCO} 3$ (Table 1), and the main minerals are goethite and quartz. The secondary minerals are calcite, aluminosilicates and gypsum. Idiomorphic quartz grains are abundant (Fig. 28), but the most spectacular aspect of sample BB30 is the presence of numerous goethite nodules observed in thin-section (Fig. 29a). There is also a sharp contact between two laminae, one rich in goethite and the other rich in clay minerals (Fig. 29b). Brownish root mats are also present (1550 in Fig. 19). These weathered mudstones and wackestones formed crusts, which exhibit common sparmicritization and micritization. All stages of gradation between micritization of grains and sparmicritization from the parent limestones to the crusts are possible.

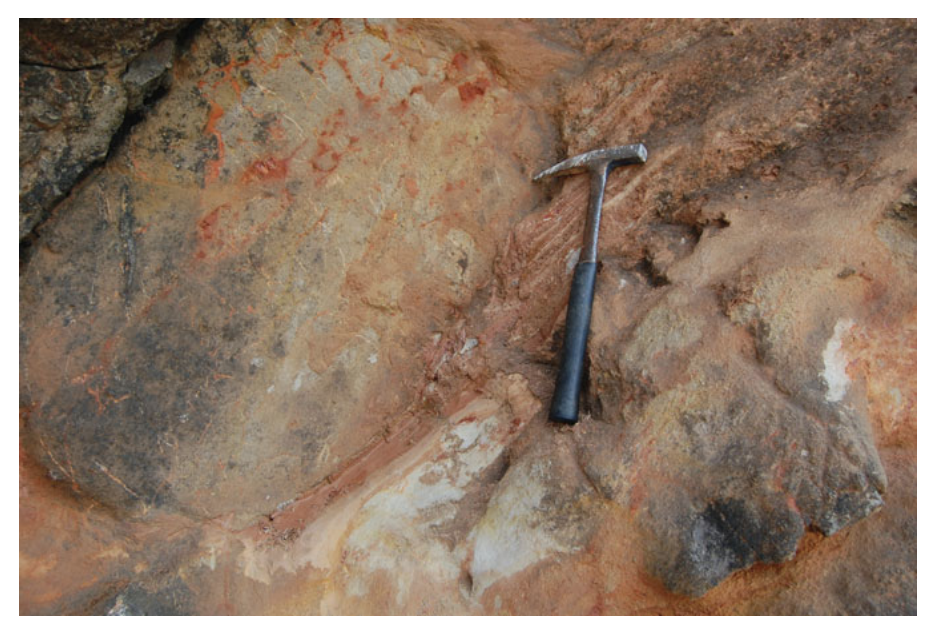

Fig. 14. (Colour online) Site A: laminae wrapping the weakly weathered parent rock (box 'e' of Fig. 9). Hammer for scale is $32 \mathrm{~cm}$ long.

Sample 1553, close to samples BB7 and BB8, was taken from a weathered reddish laminated rock (Fig. 18). It contains $4 \% \mathrm{CaCO} 3$ (Table 1). XRD analysis of the total rock shows that the main mineral is goethite associated with illite/muscovite. The clay fraction (Fig. 30) is dominated by illite/muscovite, associated with relatively abundant goethite and akaganéite, an iron oxyhydroxide $(\beta-\mathrm{FeOOH})$ reported for the first time in the studied area. Akaganéite is known to form in acid sulfate soils by oxidation of sulfide-rich sediments (Bibi et al. 2011).

Sample BB7 (Fig. 23g, h) shows smooth rounded quartz grains partially covered by thin gypsum rosettes and 
twinned crystals observed in SEM. Sample BB44, taken from the nearby small cavity, also contains the same type of rounded quartz grains (Fig. 31).

Their surfaces have a very low relief with small shock impact marks. A few grains are fractured, and the fracturing occurred after the round-shaping.
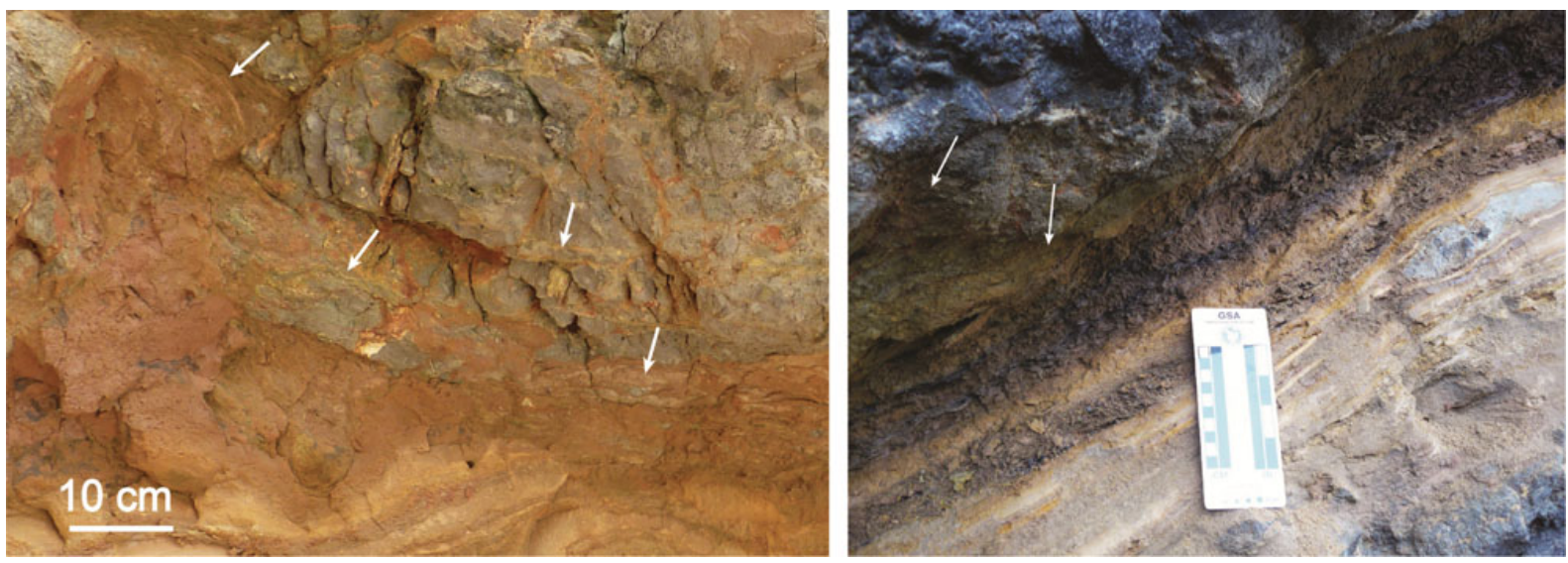

Fig. 15. (Colour online) Site A: two examples of gradual transition between loose laminae and solid or more or less weathered laminated rock (white arrows). The left picture is located above box ' $c$ ' in Figure 9. The right picture corresponds to the top of Figure 13.

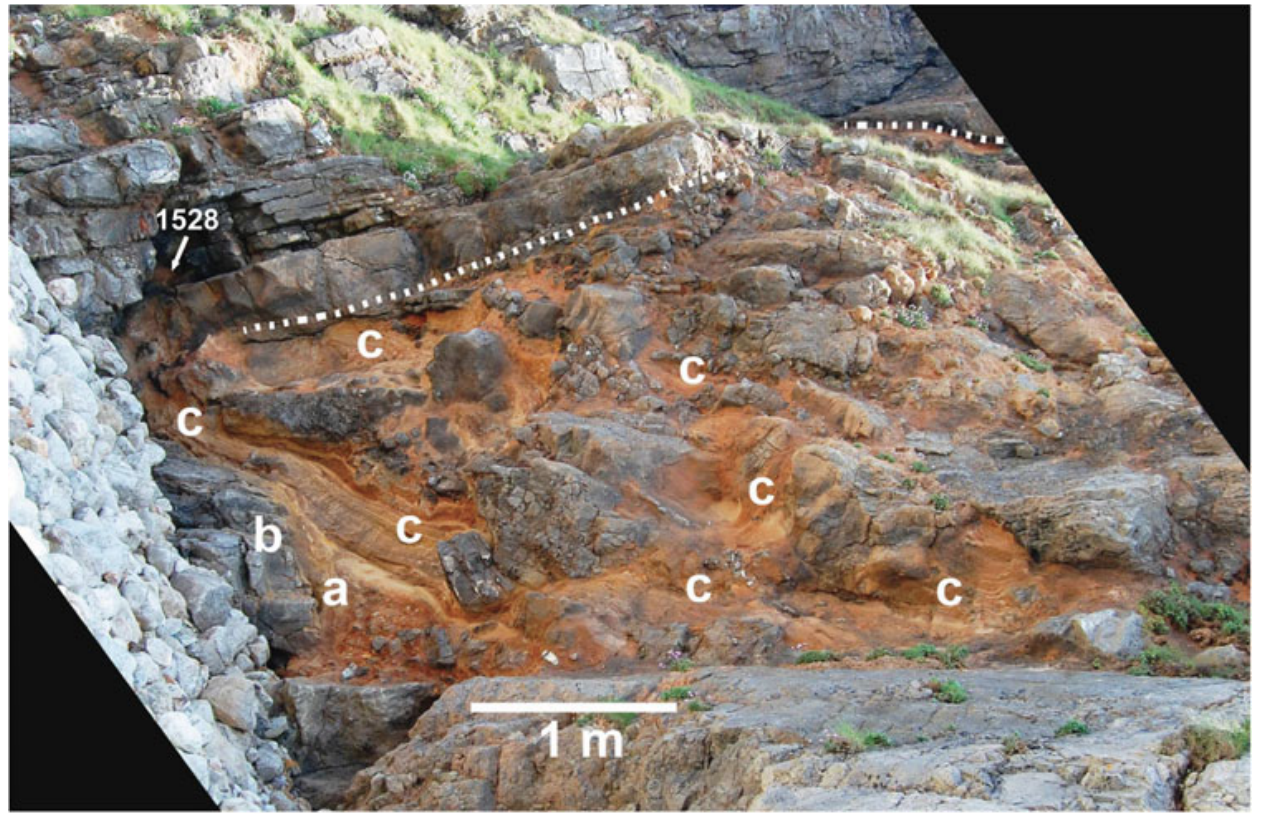

Fig. 16. (Colour online) Weathered rock and laminated sediment of site A. The picture has been straightened to show the site as it was before the Variscan folding: the limestone bed at the base of the picture has been set as horizontal. See text for comments concerning areas 'a', 'b' and 'c' and sample 1528 .

At site D, laminated formations are not frequent and the mineralogy of the weathered rocks significantly differs from sites A and B in the absence of gypsum and euhedral quartz, and the presence of pyrite (sometimes abundant) and dolomite in some samples (Table 2). Field evidence and petrographic observations of the weathered rocks indicate that the limestone parent rock suffered an intense alteration. There is no evidence of displacement in the weathered rocks. The weathered limestone host rocks consist mainly of sparmicritized matrices, as a result of calcretization of the host rocks, which suffered strong recrystallization leading to complex fabrics of 'sparmicritization' of larger calcite crystals. Sparmicritization is well developed in most of the weathered mudstones and wackestones (example of BB11-05, Fig. 7) as yellowish patchy silicification (example BB11-10, Fig. 8). This produced different mosaics, which may be interpreted as the result of multistage replacement of calcite at the expense of micrite. This analysis was not carried out systematically, but the rocks initially altered by calcretization processes 
behave very differently from those of hard limestone rocks. It is likely that the initial clay content was an important parameter, because it guided variations in microporosity.

\section{5.e. Stable carbon and oxygen isotopes}

The bulk oxygen isotopic average of the middle Carboniferous samples (Visean/Serpukhovian) is $-5.49 \%$ ( $\mathrm{n}=32)$. The values are well grouped, with no systematic trend, and range from $-6.16 \%$ to $-4.66 \%$ (except for one sample, BB11-10). The average carbon isotopic value (apart from BB11-10) is $-0.91 \%$, ranging from $-2.13 \%$ oto $1.75 \%$ (Table 3) (Fig. 32). Such values are in accordance with the oxygen and carbon isotopic records of seawater for different middle Carboniferous series in low latitudes (Mii et al. 1999; Wendt et al. 2001; Grossman et al. 2008; Saltzman \& Thomas, 2012). $\mathrm{CaCO} 3$ contents of the analysed samples range from $19 \%$ to $>98 \%$ (Table 1 ).

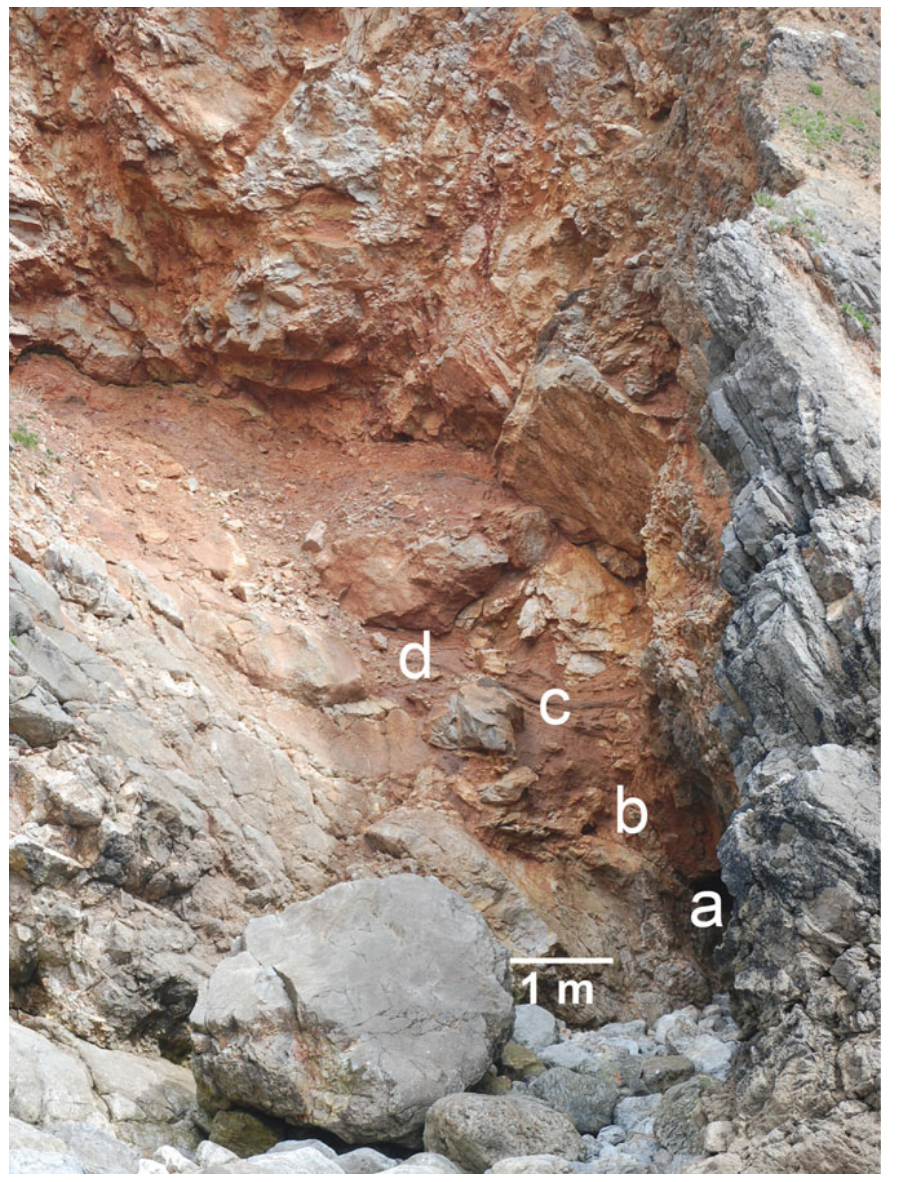

Fig. 17. (Colour online) General view of site B (from Figure 6) with placement of samples. See Figures 18 to 20 for details of 'b', 'c' and 'd'.

\section{Interpretation}

\section{6.a. Palaeoenvironment}

\section{6.a.1. Petrographic data}

Microfacies 1 is characteristic of an open marine (echinoderms, brachiopods and algae), shallow subtidal environment, with high degrees of agitation and slightly elevated salinity (Carew \& Mylroie, 1997). In this shallow environment, the sediment was frequently reworked by currents as shown by the cross-stratification of the oolites and bioclasts, which formed sandy bars or shoals (Fig. 21a, b). Peloidal irregular and laminoid fenestral fabrics in the packstone facies (Fig. $21 \mathrm{c}-\mathrm{h}$ ) display evidence of intertidal- supratidal diagenesis related to temporary subaerial exposure, as also highlighted by meniscus cements in the fabrics (Tanner, 2010). Cementation of intergranular pore spaces between 
oolites and bioclasts led to the formation of beachrocks in the grainstone (Fig. 21a, b). The tiny irregular lamellar and meniscus cements in both facies (packstone and grainstone) point to a vadose influence, followed by equant blocky calcite in the phreatic environment (Land, 1989; Moore, 1989), as highlighted by larger calcite crystals around the pore walls or inside the dissolution cavities. These blocky calcites follow the irregular bladed rim or pendant cements of the first calcite precipitation (James \& Choquette, 1990). Epitaxial growth on echinoderm plates is also observed in this phreatic environment. Micritic grain coats, tubiform rootlet moulds associated with anastomosing cracks and pisolites suggest that the bioclastic and oolitic substrate was calcretized and led to a crudely laminar fabric with distinctive darker and denser laminae.

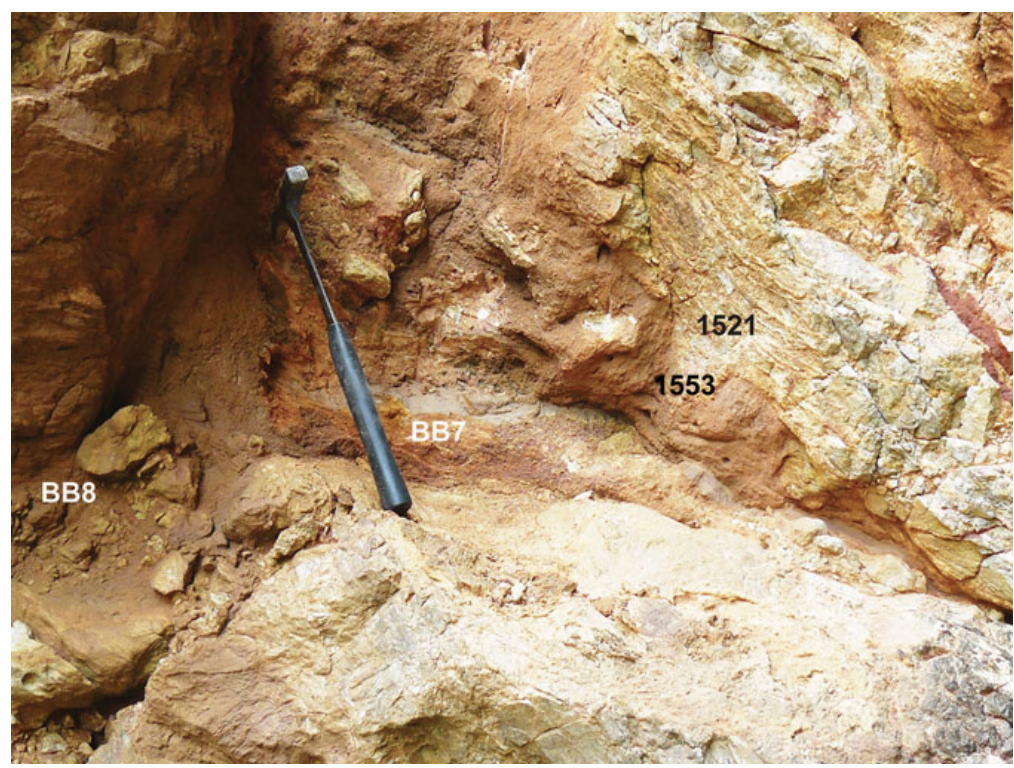

Fig. 18. (Colour online) Detail of site B ('b' in Fig. 17). Hammer for scale is $32 \mathrm{~cm}$ long.

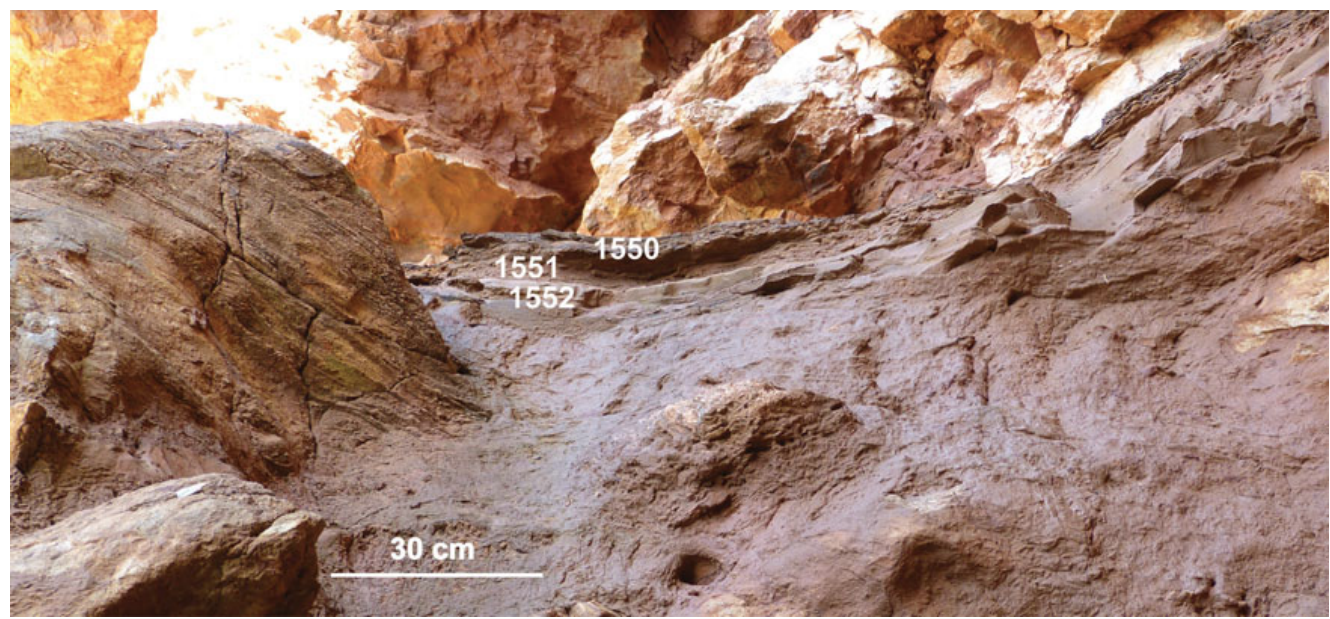

Fig. 19. (Colour online) Detail of site B ('c' in Fig. 17). Note the lamination in the nearby solid rock.

Evidence of subaerial exposure is also highlighted by the gravitational cements associated in the vadose diagenetic environment with the tubular voids, which could represent fine root tubules (Fig. 21d-h).

Microfacies 2 consists of fine-grained carbonates (mudstones/ wackestones) with a few bioclasts of reduced diversity, which formed in a lagoonal setting in very quiet conditions. They probably represent protected coastal lagoons behind offshore barriers (with bioclastic shoals, see microfacies 1 in Section 5.d) (Hardie, 1977). The common fenestral fabrics (Fig. 22) point to intertidal and supratidal environments (Flügel, 2004). The facies records the 
influence of pedogenesis (rootlets, alveolar structure; Fig. 22g, h) according to Wright \& Tucker (1991). This is supported by the large-sized irregular sparmicritized fenestral fabrics (Fig. 22a-f) connected to thin tubules or veins leading to the formation of calcrete crusts. Thin fibrous to microbladed calcite cements on the roof of the fenestrae (Fig. 22g) also suggest a vadose influence. Blocky equant calcite (often centripetal) crystals are also commonly observed in the fenestrae and cavities (Fig. 23a, b), as probable Microcodium clasts.

Based on the above facts, microfacies 1 and 2 recorded deposition in shallow water (respectively high and low energy). Then, they were subjected to significant subaerial exposure (beachrocks and calcretes) and later passed into the meteoric phreatic environment, as suggested by the blocky equant cement (Fig. 23c, h) filling dissolution cavities and residual intergranular porosities. Subsequent sparmicritization of the cemented cavities points to multiple diagenetic vadose-phreatic phases (Fig. 23e, f).

\section{6.a.2. Laminated facies of sites $A$ and $B$}

At site A, the graded lamination characterizes the sediment, which is dominantly silty, with temporary inputs of coarser sediment. This type of feature can be observed in various aqueous environments; for example, in the swashbackwash zone of beaches, but also in supratidal flats (lagoons and sabkha) with laminar flow and abundant suspended sediment, with possible short flash flooding. The good preservation of lamination and the absence of bioturbation, the fenestral fabric and vadose features, and the mineralogy (abundant euhedral microquartz and gypsum, halite pseudomorphs after gypsum) suggest high-salinity conditions, in intertidal or supratidal salt flats (sabkha) during hot and arid climates with comparatively low humidity and rapid evaporation (Logan, 1987; Schreiber \& Walker, 1992). All the fossils found in the laminae are the same as those of the solid rock. They are well dated from the early Brigantian, thanks to a conodont assemblage (Błażejowski \& Walsh, 2013). Late Visean conodonts have been recognized in shallow-water platform limestones in Ireland (Somerville \& Somerville, 1998). Thus, it is not excluded that the fossils present in the laminae could date the sedimentation itself.

The arrangement of the loose laminae, either parallel and in continuity with laminated solid rock, or either oblique and in sharp contact with the solid parent rock, cannot be explained in a single sedimentation event but by a complex sequence of successive events: (i) meteoric erosion during a low sea-level and emergence period leading to a rough rocky platform; (ii) laminar sedimentation in an intertidal, supratidal or lagoonal environment, which skirts and wraps the small-sized rocky stumps of the platform; (iii) early diagenesis and weathering of laminated rock in hypersaline and oxidizing conditions in a sabkha-type environment. More than one period of emergence and temporary surface exposure is possible in this sequence as highlighted by Fe-pisolites. This sequence was followed by a transgressive phase of marine sedimentation marked by a slight unconformity of a limestone bed over the laminated weathered formations. Site A is the only place in Bullslaughter Bay where it is possible to recognize such a complex sequence of events.

At site B, despite their small size, the patches of laminated sediments provide valuable palaeoenvironmental information. As in site A, the ubiquitous bipyramidal quartz grains and the abundance of gypsum strengthen the hypothesis of one or several phases of sedimentation in a hypersaline environment (supratidal salt pan or sabkha), which is also reinforced by the presence of akaganéite (see Section 6.a.3 below). On the other hand, the rounded and larger quartz grains observed in two samples of site B (Figs 23g, h, 31) have a different origin. They are detrital. Their shape and surface features suggest marine abrasion on a beach (Krinsley \& Doornkamp, 1973; Le Ribault, 1975). Such an origin is reinforced by the microscopic characteristics of samples BB43 (Fig. 21a) and BB8 (Fig. 23a-e). A temporary beachrock environment is compatible with these observations. 


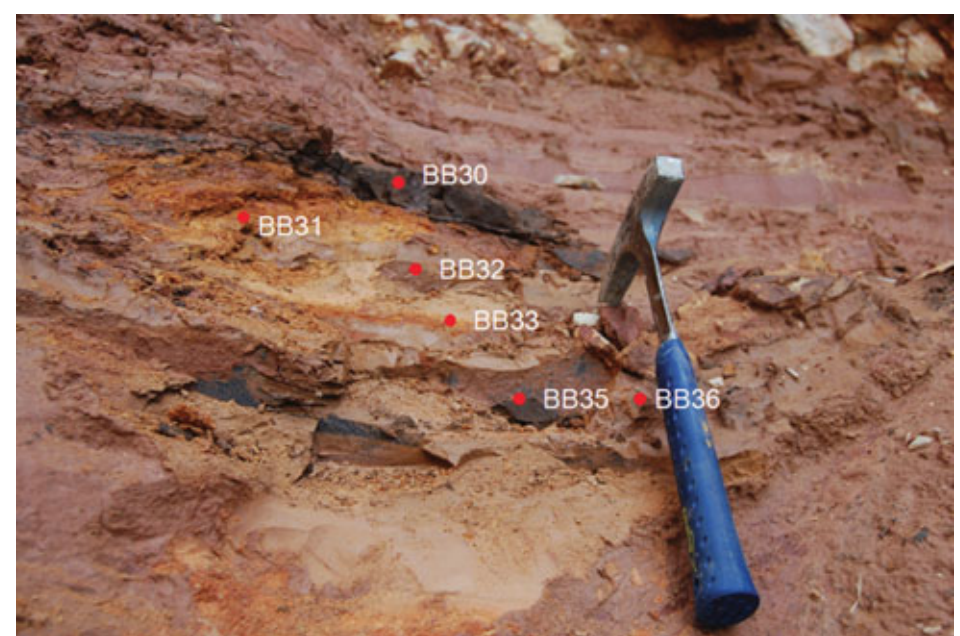

Fig. 20. (Colour online) Detail of site B ('d' in Fig. 17). Hammer for scale is $28 \mathrm{~cm}$ long.

The good crystalline shape of gypsum in sample BB7 (collected in loose material close to the more or less weathered 'BB8' limestone) proves that the sediment was not disturbed after the formation of gypsum despite the presence of a nearby slightly collapsed limestone and fault zone.

De-dolomitization has also been observed in site B (thin-section 1521) in a ferruginous peloidal wackestone with large-sized macrosparitized calcite crystals (up to $1 \mathrm{~mm}$ ) and calcitized dolomite (up to $500 \mu \mathrm{m}$ ). This latter consists of large rhombs (up to $1 \mathrm{~mm}$ ), isolated or contiguous, comprising a fine-grained mosaic of euhedral calcite. Calcite pseudomorphs after prismatic evaporite crystals (gypsum?) are also observed as millimetric irregular vugs, with pendant calcite cements. Meteoric water can dissolve former evaporite crystals including dolomite. The dissolution and replacement of evaporite can also occur by undersaturated waters from underlying and adjoining aquifers, without recharge from the surface (Schreiber \& El-Tabakh, 2010). The calcitization of gypsum requires a supply of $\mathrm{Ca}^{2+}$ and $\mathrm{CO}_{3}{ }^{2}-$ and the removal of $\mathrm{SO}_{4}{ }^{2-}$. However, these processes can occur either at different times (i.e. with earlier formation of voids by dissolution) or simultaneously (Armenteros, 2010).

\section{6.a.3. Hypersaline environment in sites $A$ and $B$}

The bipyramidal quartz grains are characterized by an imperfect habit with numerous small vacuoles due to disturbance during the crystallization process. It suggests a rapid precipitation after former silica solution. Different sources of silica were possible (hydrolysis of clay minerals, solute load in fluvial or deltaic influx, solution of cherts, silica released from skeletal grains). Thus, the problem is not the source of silica but the conditions of crystallization. Euhedral quartz can form at a high temperature owing to deep burial or a hydrothermal environment. Here, such a context can be excluded, because of the perfect preservation of halite pseudomorphs and gypsum crystals in some laminae, and the limited compaction and absence of burial diagenesis in all the samples that were analysed. On the other hand, this type of euhedral quartz habit has been described in hypersaline sedimentary environments, in supratidal or inland areas such as sabkhas or salt pans (Grimm, 1962; Friedman \& Shukla, 1980; Paszkowski \& Szydłak, 1986; Gundu Rao, 1986; Viczian, 1992; Ulmer-Scholle et al. 1993; Albright \& Lueth, 2003; Flügel, 2004). According to the latter authors, the neo-crystallization of quartz is possible in the presence of salt solutions. At sites A and B of Bullslaughter Bay, the process of quartz crystallization by the replacement of sulfate is strongly suggested by SEM micrographs (Fig. 24b) showing juxtaposition of bipyramidal quartz and gypsum crystals. The absence of bipyramidal microquartz and gypsum in the more recent Brigantian limestone strata of site D (north of the Bullslaughter Bay syncline) is an argument to constraint the time of their formation and to relate them to a period of sea-level lowstand and emergence prior to late Brigantian time. 

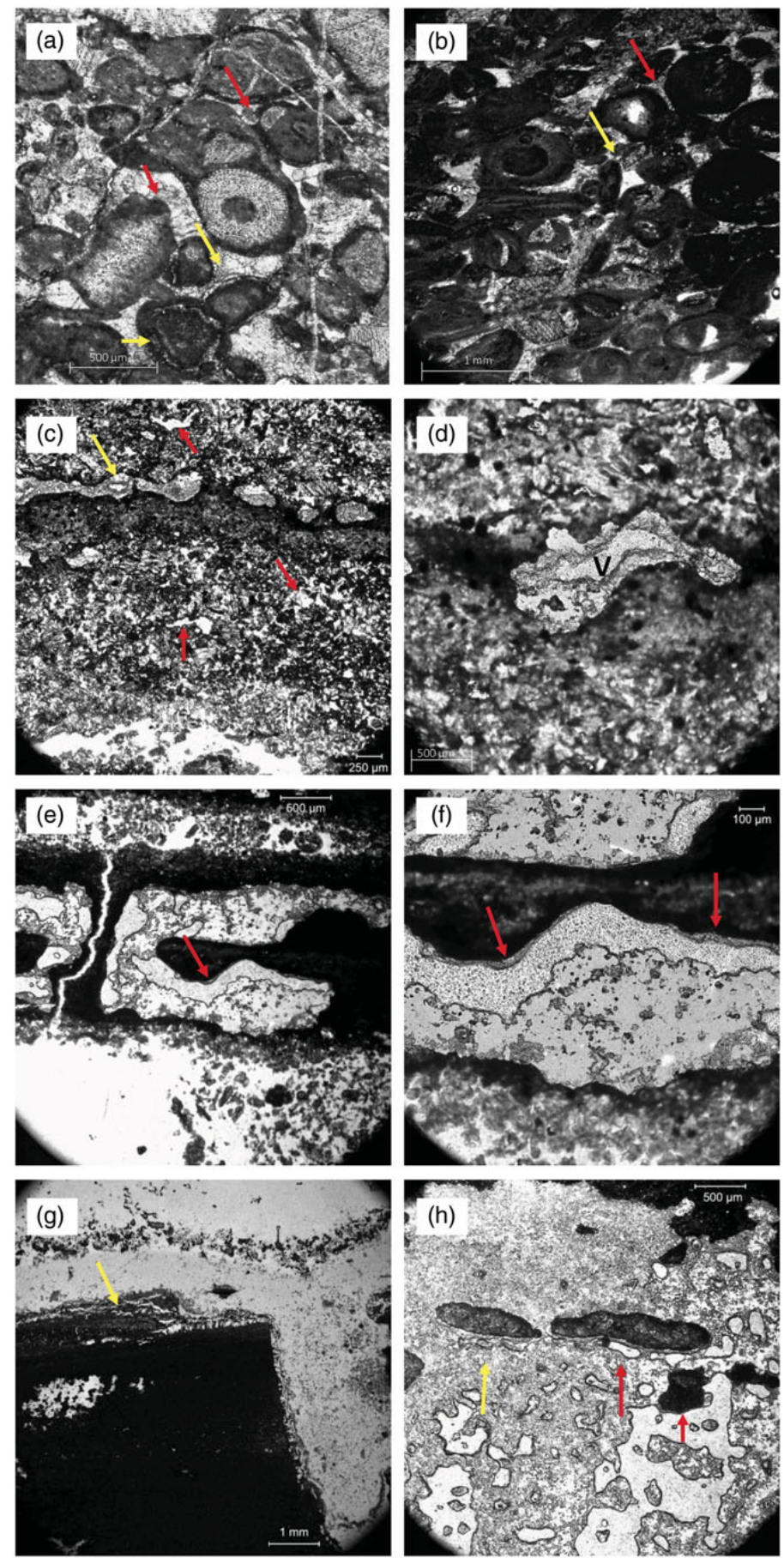

Fig. 21. (Colour online) Thin-section photomicrographs of grain coatings and spar-filled voids (A. Préat, 2018). (a) Sample BB43/a, site B. Bioclastic grainstone with micritized (mollusc) and pitted (crinoid) grains coated by dark micrite with irregular thicknesses around the lumpy grains (large grain in centre). Thin irregular rim of equant (microblocky) calcite cement inside or around micritic grains (yellow arrows). It is followed by wide lamellar (red arrows) and coarse or granular calcite cements (white zones in the centre of the former voids). The bioclasts are totally or partly micritized. Compaction is very weak. (b) Sample BB11, site D. Bioclastic (crinoids, molluscs) and oolitic grainstone with a discrete oblique stratification, showing strong micritization of the oolites (lower part of the photo) and other grains (micritized grains). Same irregular microblocky (red arrow) and large bladed calcite cements as observed in (a), and calcitic meniscus cements (yellow arrow), followed by white granular calcitic cements (centre of the former voids). Most of the grains are coated by a dark micritic cortex leading to the formation of 'ooidic-oncoidic' grains. The distribution of the cements is heterogeneous. Compaction is very weak. (c-h) Sample 1512, site A: (c) Microsparitized peloidal packstone showing a small-sized irregular and tubular fenestral fabric (red arrow). Most of the microspar consists of acicular and lamellar calcite crystals. Laminoid fenestrae (upper part, yellow arrow) are filled with an equant calcite cement. Scale bar in lower left corner is 250 um; (d) clotted peloidal microsparitic packstone with an irregular fenestra representing a calcified root inside a darker micrite (not microsparitized). Individual smallsized blocky and isometric calcitic crystals bordered by a thin internal microsparitized layer constitute the 'cortex' of the fenestra. The void (V) (centre of the fenestra- root) is empty; (e, f) large irregular laminoid fenestral cavities with gravitational cements (red arrows) composed of very fine blocky calcitic crystals. The cavities were formed in a dark mudstone and are interconnected through a thin subvertical microchannel (e); (g) very large irregular cavity, with a general tubular subvertical cylinder (whitish area bordering the right side of the photograph) affecting the dark micrite matrix. The micritic relic is bordered by two medium-grained lamellar calcitic cements separated by a dark micritic discontinuity (with solution features) forming a thin layer, more irregular on the vertical wall. This cement is also bordered by a very thin greyish micrite lamina, which fills a probable shrinkage crack. Other anastomosing very thin empty shrinkage cracks are on the top of the micritic relic block (yellow arrow); (h) greyish to darkish microsparitized mudstone relics (yellow arrow, below an elongated relic) in a homogeneous microsparite with abundant large irregular and tubular empty vugs or fenestrae. The vugs are bordered and interconnected by thin laminar coatings, sometimes with pendant cements consisting of very fine-grained microblocky calcite below an empty vug (red arrow in the centre) and below a mudstone relic (right red arrow). 

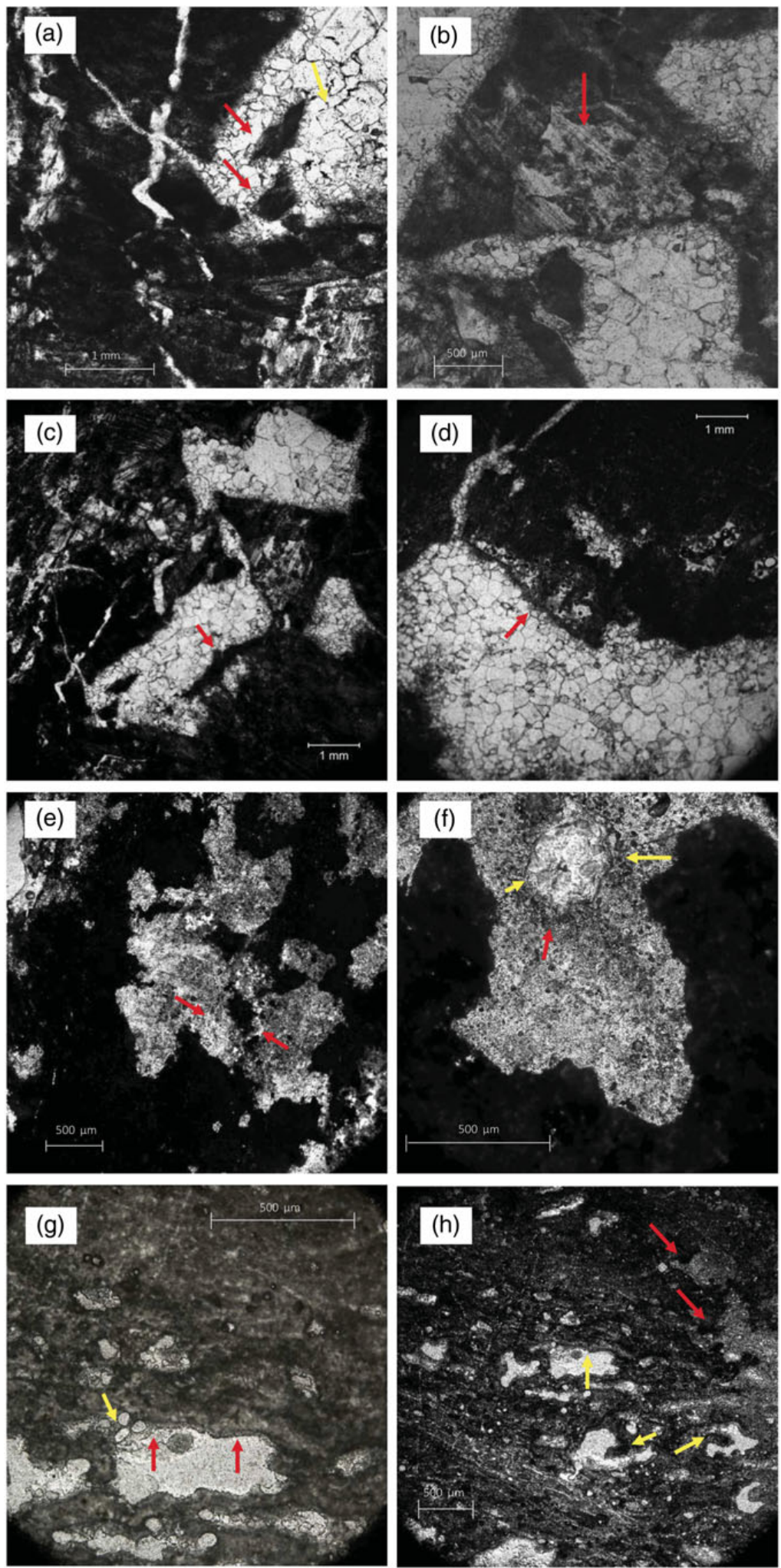

Fig. 22. (Colour online) Thin-section photomicrographs of fenestral fabrics in dark mudstones (A. Préat, 2018). (a-d) Sample BB39, site B. Slightly microsparitized (bioclastic) packstone with large-sized irregular fenestral-like cavities connected to thin tubules or veins. The cavities in the micrite are lined by two replacive calcite cements, the first one being lamellar or bladed (red arrow in (a)), the second one being blocky or equant (yellow arrow in (a)), and sometimes centripetal ((b) and lower cavity in (c)). Remnants or relics of former matrix are present in the cavity and generally bordered by the first lamellar calcitic cement phase (a). Partly leached and micritized grains are also observed ((a) lower right corner). The veins are sometimes empty, or cemented with walls consisting of small-sized equant calcitic crystals (d). Long acicular prismatic calcite crystals could also replace differently the matrix or are present in the matrix as possible Microcodium ((b) red arrow). The grain is slightly micritized and contains irregular peloids. Irregular and limited networks of micrite walls are present in the cavities ((c) and (d) red arrows) and could represent deposition of fine-grained carbonate around decaying organic matter (rootlets)? (e, f) Sample BB11-05, site D. Dark mudstone with irregular/ tubular fenestral fabric showing intense sparmicritization. Peloidal relics of the mudstone are preserved ((e) red arrows) as a calcite void or tube (rootlet or some organism? in (f), yellow arrow), which pushed small-sized pellets aside (red arrow). A very thin micritic layer surrounds the tube $(\mathrm{g}, \mathrm{h})$ Sample BB2, site D. Microsparitized dark mudstone with abundant more or less stratified irregular and fingered ((h) yellow arrows) fenestrae. The tubular fenestrae are sometimes complex, containing other small-sized tubes ( $(\mathrm{g})$ yellow arrow). Thin microbladed cement is preferentially observed in the roof of the fenestrae $((\mathrm{g})$ red arrows $)$ 

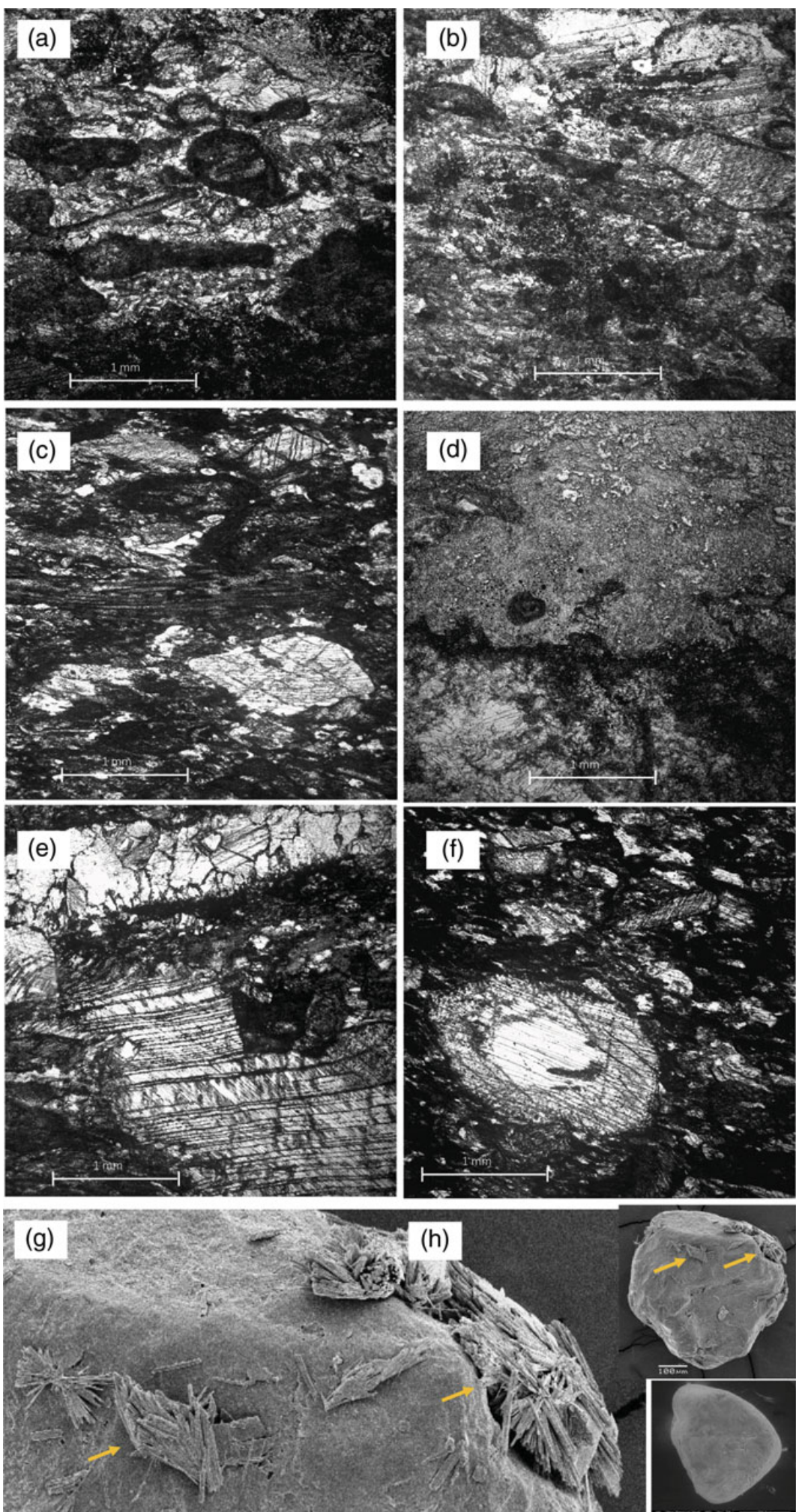

Fig. 23. (Colour online) Photographs of (a-h) weathered limestone and $(\mathrm{g}, \mathrm{h})$ quartz grains. (a-e) Thin-section of sample BB8, site B (A. Préat, 2018). Strongly recrystallized (aggrading neomorphism) (whitish zones in $(a, b))$ poorly laminated packstone with coated grains and micritized and bioclasts (mainly pelecypods in $(a, b)$ and algae (central part of $(\mathcal{C})$. The micritic matrix is microsparitized (irregular greyish dirty zones, lower part of picture and upper left corner of (a), main part of (b)) with irregular peloids, and irregular and surrounded relics of the former dark micrite upper half of (d). Coarser crystals, associated within the microspar, indicate that sparmicritization occurred (upper part of (b)). Recrystallized larger (millimetre-sized) calcite crystals, with strong varying direction of twin lamellae, highlight intensive stress tectonic processes (c), also highlighted in (e) with calcite-filled (two generations) fracture. (f) Thinsection of sample BB37, site B (A. Préat, 2018). Bioclastic packstone dominated by large crinoid pieces. Although the pieces are more resistant than other bioclasts, they suffered dissolution (white central part, bottom) and varying direction of twin lamellae. (g, h) BB7, site B (C Lenka Křižova', 2016). Gypsum rosettes (diameter 100-200 $\mu \mathrm{m}$ ) and isolated gypsum laths (length $20-50 \mu \mathrm{m}$ ), which have precipitated on rounded quartz grains. 
(a)

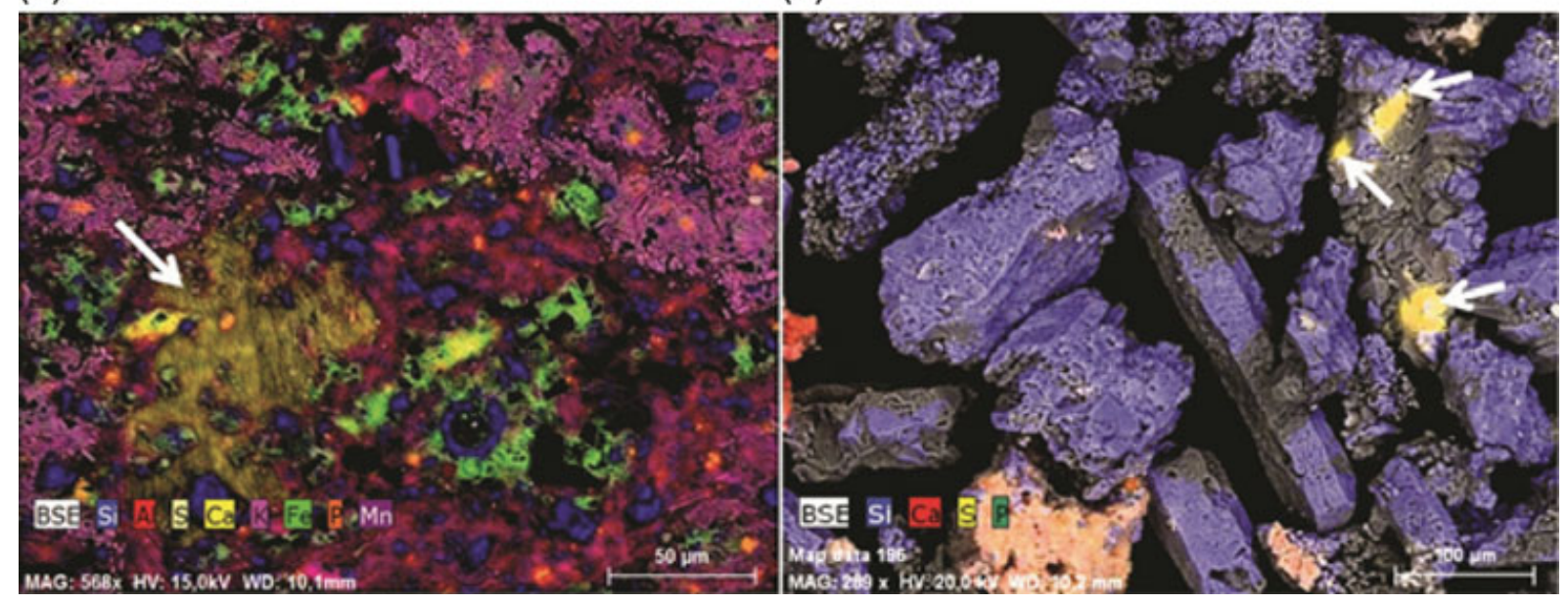

Fig. 24. (Colour online) SEM photomicrographs and EDX analysis of samples of site A. (a) Thinsection of sample 1513 with fibrous gypsum (white arrow), small euhedral quartz and iron oxides in a matrix of clay minerals. (b) Selected particles of sample BB11. Euhedral quartz. Note a cluster of very small euhedral quartz with micro-patches of (residual?) gypsum (white arrows)

(a)

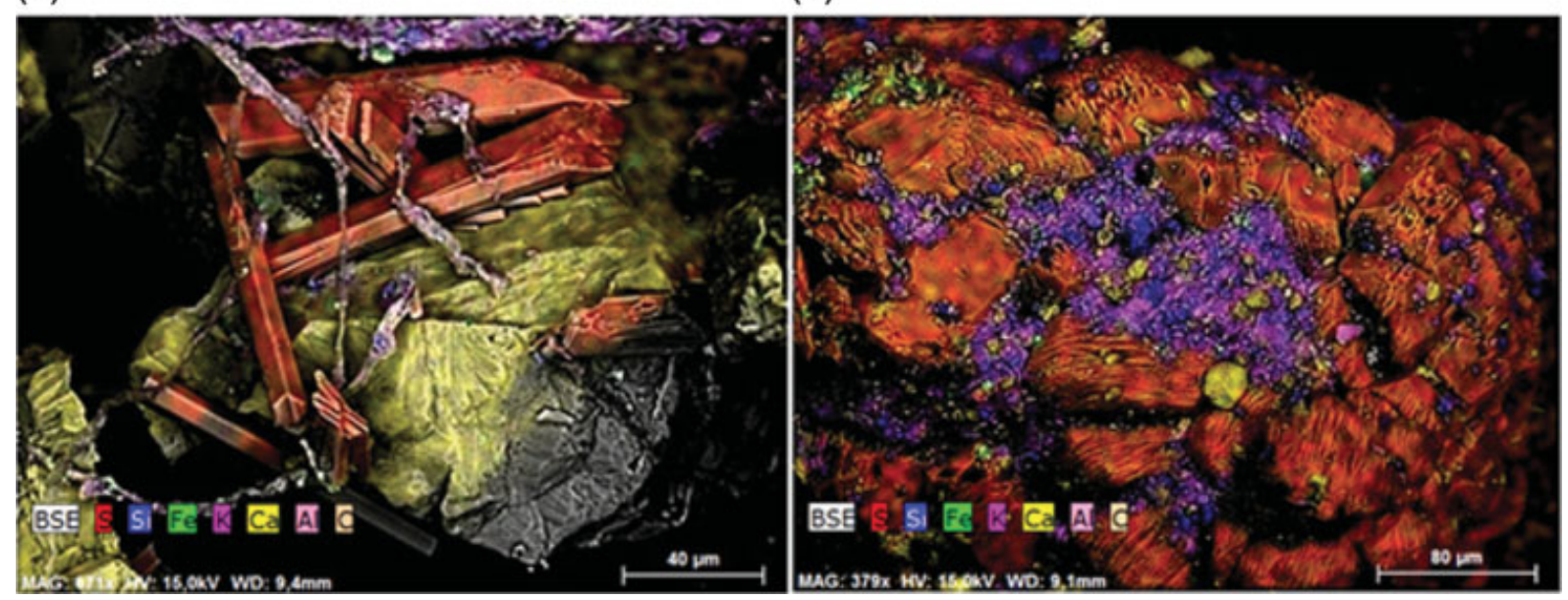

Fig. 25. (Colour online) SEM photomicrographs and EDX analysis. (a) Sample BB7: gypsum laths. (b) Sample BB8: gypsum crystals and silica.

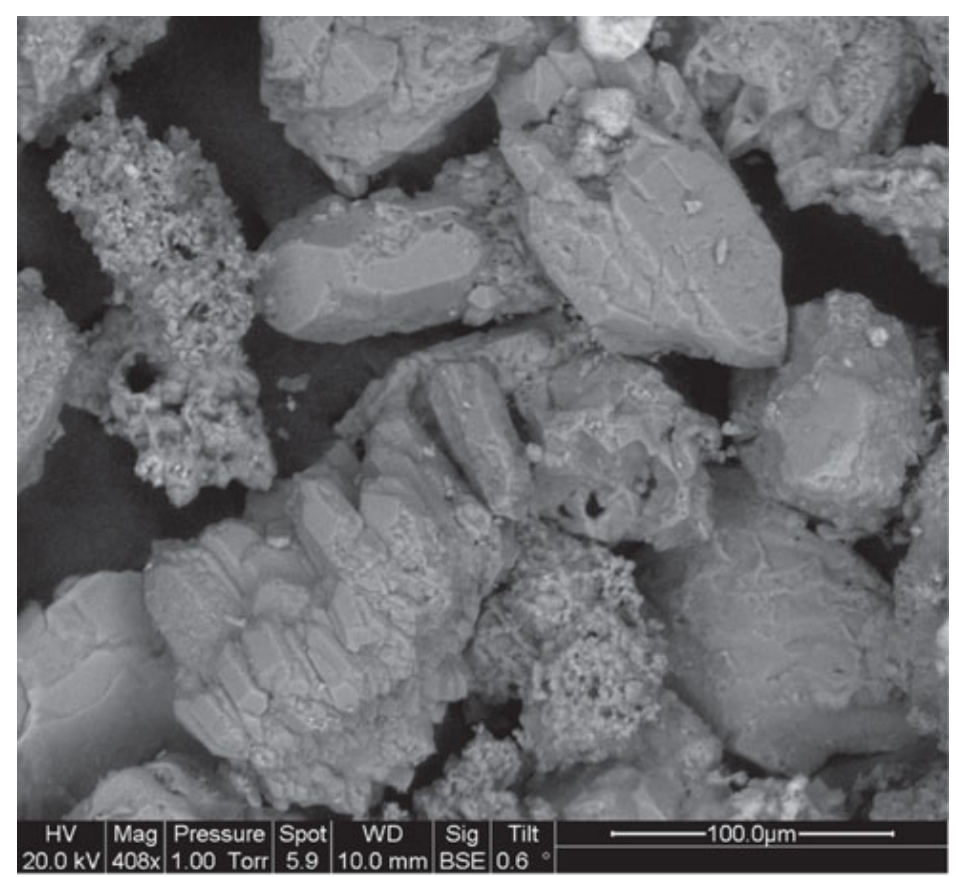

Fig. 26. (Colour online) SEM photomicrograph of euhedral quartz (here in sample BB11). 

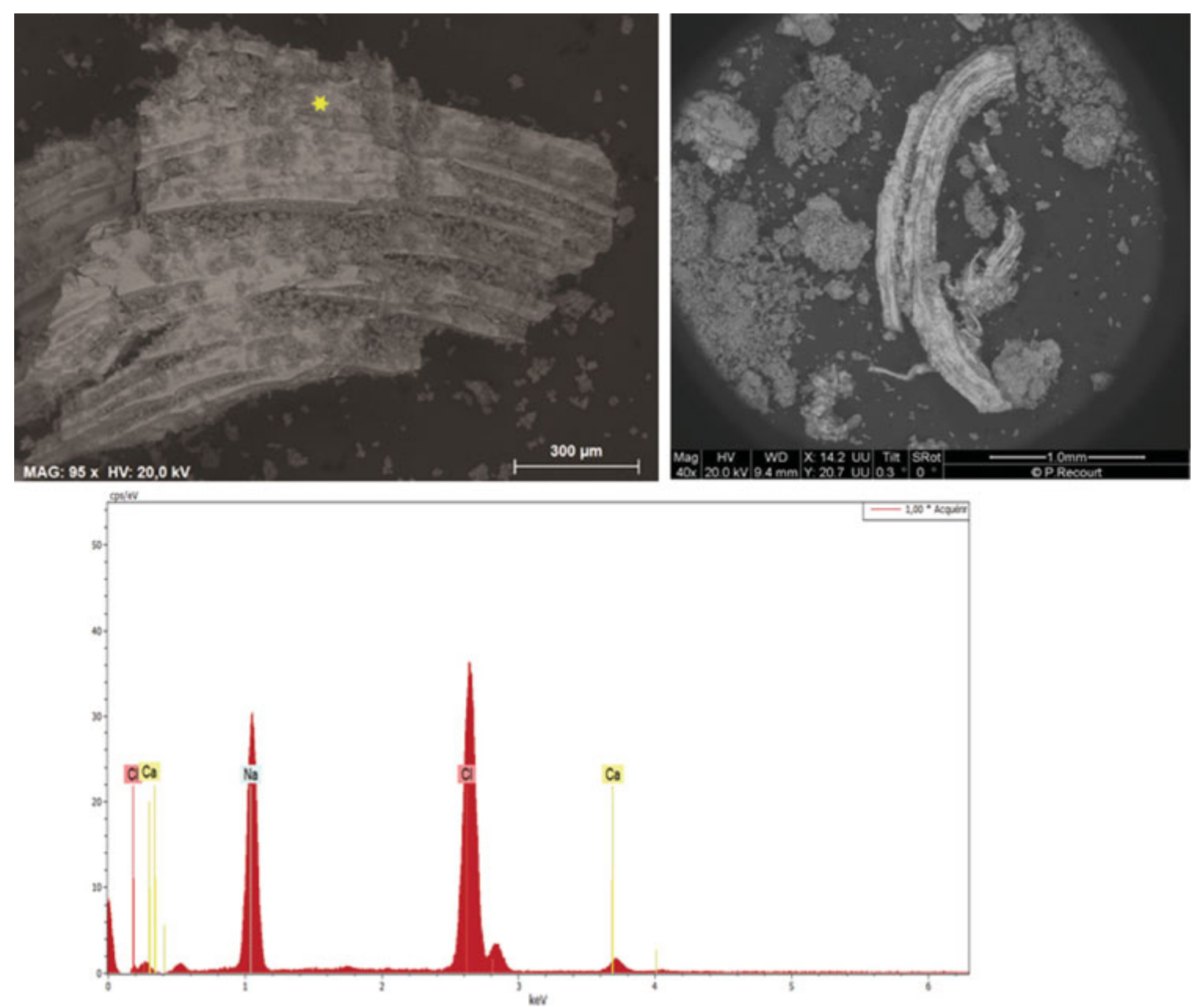

Fig. 27. (Colour online) Halite pseudomorphs after gypsum, in sample 1531 (SEM photomicrographs and EDX analysis).

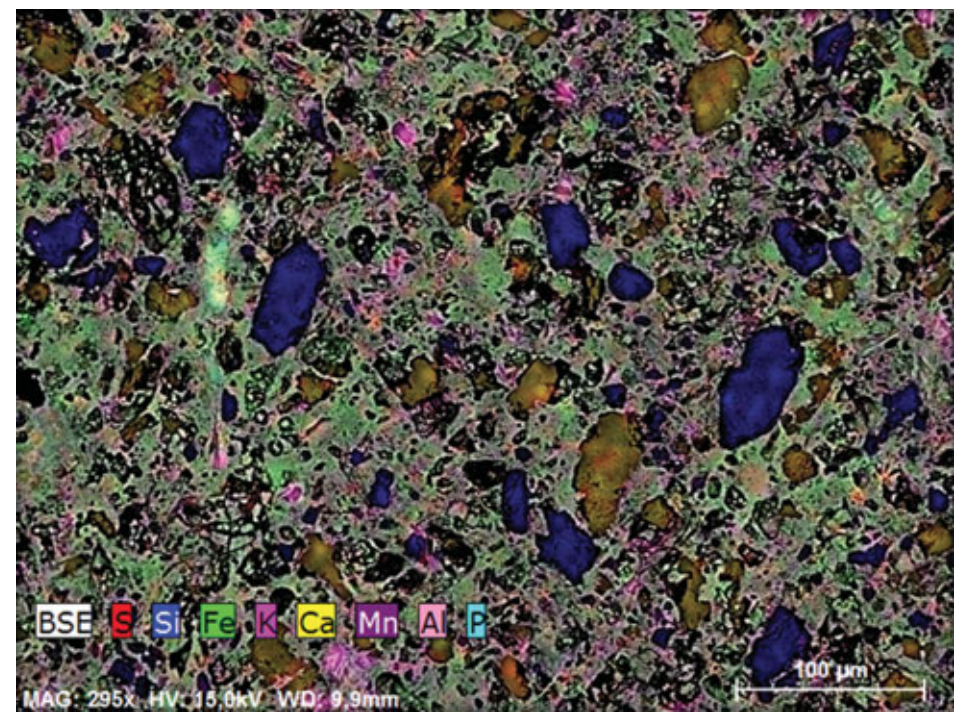

Fig. 28. (Colour online) SEM photomicrograph and EDX analysis of a thin-section of sample BB30. Abundant quartz grains. Many of them are idiomorphic.

Our hypothesis of a hypersaline environment is also supported by the presence of akaganéite associated with goethite and gypsum in sample 1553 at site B. Akaganéite has been described in a highly saline inland wetland (the Bottle Bend Lagoon) in the southwest of New South Wales (Australia) (Bibi et al. 2011). The precipitation of akaganéite followed a sharp fall in $\mathrm{pH}$ (from 8 to 3) owing to a severe drought event in 2002. Halite and gypsum crystals are 
always very abundant in the Australian samples containing akaganéite. It is interesting to note that the thin-section of sample 1553 revealed a very fine-grained whitish homogeneous microsparite with Fe-peloids (goethite) and enterolithic-like microveins filled with thin palissadic gypsum. Moreover, sample 1553, which contains only $4 \%$ $\mathrm{CaCO} 3$ (Table 1), is close to $\mathrm{BB} 7$ and BB8, which are rich in gypsum crystals. Finally, one of the best arguments supporting the hypersaline environment hypothesis is the presence of pristine halite pseudomorphs after gypsum. Although infrequent in the geological record, the replacement of gypsum by halite has long been known, especially in Permian rocks. The process was analysed in relationship to the environmental context and the solubility relationships of gypsum, halite, anhydrite and brine (Schreiber \& Walker, 1992; Hovorka, 1992). Despite some divergent explanations, these authors agreed that the replacement takes place in shallow-water hypersaline basins. For Schreiber \& Walker (1992), the process implies hot and arid climates and needs contrasting temperatures between the brine surface water (which must be 'overheated' up to $55-57^{\circ} \mathrm{C}$ ) and the underlying sediment. It involves brine convection and provides the saturation relationships necessary to both dissolve gypsum and precipitate halite. It occurs most easily in shallow-water bodies with solar heating of the brine favoured by blooms of red-pigmented bacteria. The replacement takes place just below the sediment surface and concerns a very thin layer (generally less than $10 \mathrm{~cm}$ ).

The hypersaline environment suggested by our petrographic and mineralogical analyses may be compared with the present salt pans called 'tannes' in Africa. They are situated in the tropical climate zone with contrasting dry and rainy seasons on the landward side of mangroves. Their formation needs a dry season lasting over three months, but the climate must be wet enough to allow the mangrove development. The acid sulfate soils of these 'tannes' have been studied in Senegal (Sadio, 1991). Marine pyrite is the main source of sulfur. Oxidation of pyrite gives jarosite, lepidocrocite, goethite and haematite according to the topographic and hydrological environment. The $\mathrm{pH}$ of soils may be very low (down to 3 in some cases) and the salinity five to ten times that of the seawater. A few decimetres relief is sufficient to change the $\mathrm{pH}$, drainage conditions and geochemical processes. In the lower parts gypsum is abundant. On slightly higher areas with better drainage and low $\mathrm{pH}(<4)$ goethite forms. At the top with efficient drainage and very high salt content, ferric of ferro-manganese concretions can form. In Senegal, these acid sulfate soils are able to develop in a few dozen years. This African case helps to understand what happened in the Late Mississippian environment of Bullslaughter Bay. At sites A and B, the juxtaposition of gypsum-rich and iron/ manganese-rich laminae could be explained by a type of coastal environment similar to the present Senegal salt pans. If the pH was possibly as low as in Senegal, the solution of the local limestones could have been very rapid. At sites A and B, the parent rocks were iron-rich muddy limestones. The goethite nodules are often associated with manganese. They could be compared to iron-manganese nodules observed in the semi-arid climate of northeastern Spain. Sanz et al. (1996) considered that they were formed in situ in a poorly drained soil with a high calcium carbonate content. According to these authors, Fe and Mn redistribution in soil is caused by water table oscillations.

\section{6.b. Stable isotopes (oxygen and carbon)}

The isotopic compositions of carbon and oxygen (when the decalcification was not too strong to allow analyses), which are the same in both cases (see below), confirm that the genesis of the alteration was related to a meteoric influence. The general processes could be attributed to a 'grainification' of the parent materials, producing secondary diagenetic matrices in the context of the general textural inversion, which is characteristic in calcrete or in pedogenic carbonates (Wright \& Tucker, 1991).

A crucial question in any study of carbonate chemostratigraphy is whether a primary marine signature is preserved. As we have seen in the sedimentology section, the limestones studied were deposited in a marine environment (see, for example, the bioclastic and oolite contents), but the typical cements of this environment (aragonite, fibrous high-Mg calcite (HMC) or elongated bladed HMC) have not been preserved and have been 
(a)

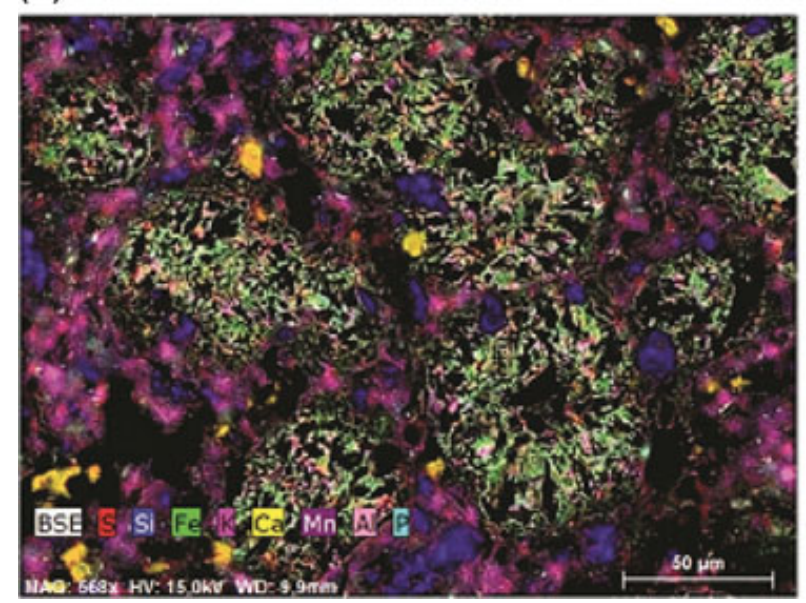

(b)

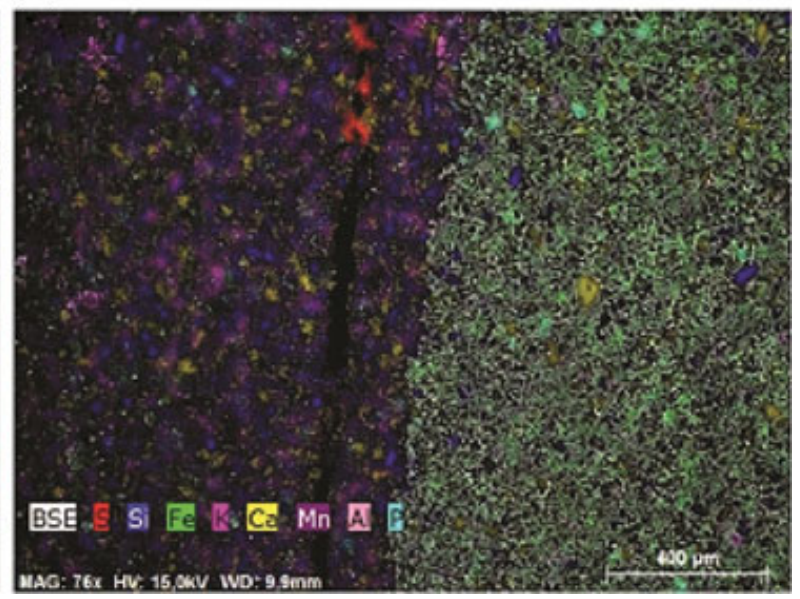

Fig. 29. (Colour online) SEM photomicrographs and EDX analysis of a thin-section of sample BB30. (a) Goethite nodules. (b) Sharp contact between two different mineralogical laminae.

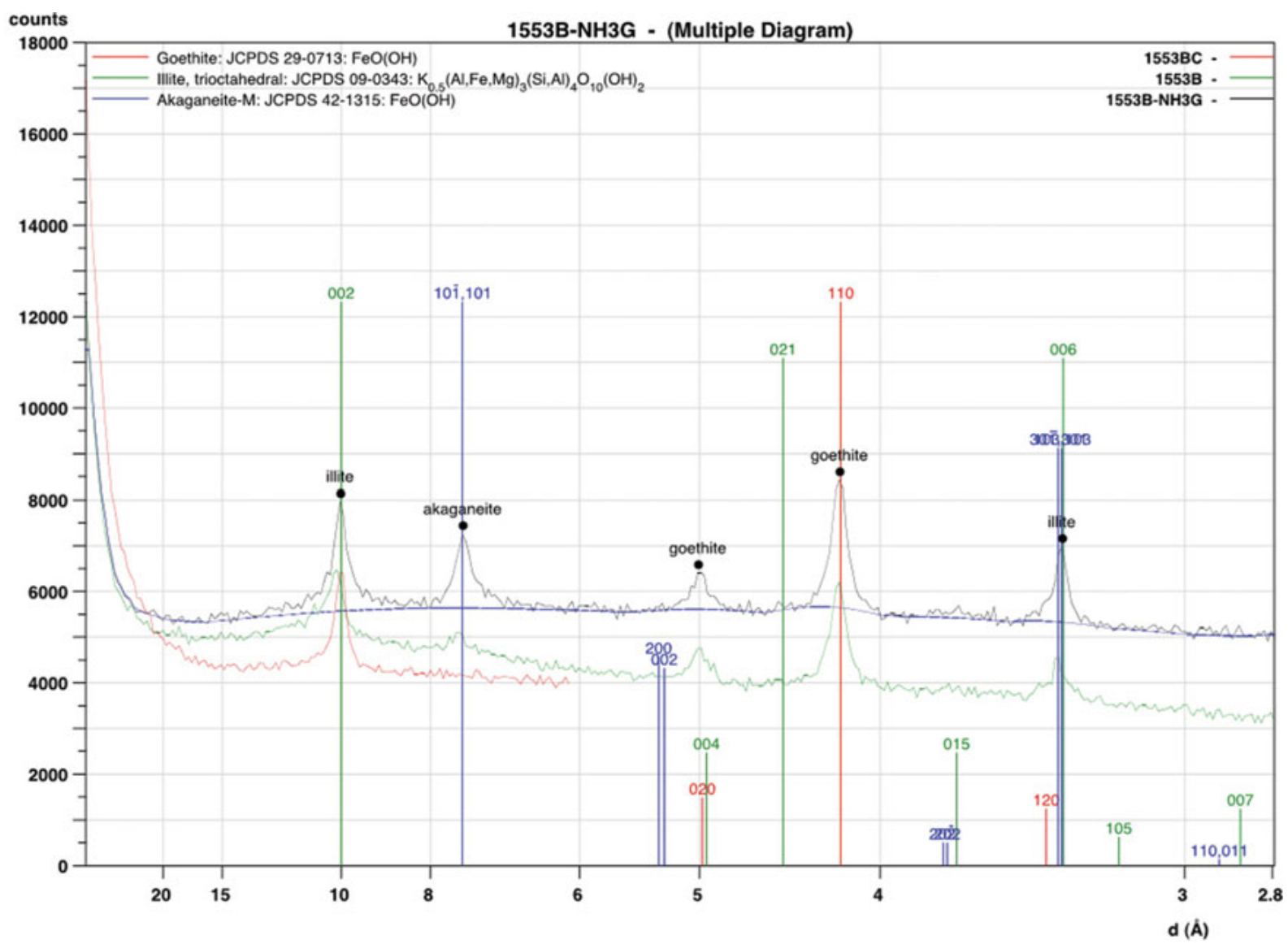

Fig. 30. (Colour online) XRD diagram of sample 1553 containing illite, akaganéite and goethite (source: Viviane Bout-Roumazeilles, CNRS-LOG-University of Lille).

replaced by lamellar and equigranular or coarse crystals of calcite (low-Mg calcite), both in the intergranular space and in the fenestral-type dissolution cavities. The pendant cementation and vadose cavities observed in these Visean limestones, as well as the beachrocks, also show that the diagenetic alteration was early, as also attested to, for example, by the absence of compaction patterns in the alveolar structures. The primary chemical signature (marine domain) has therefore been altered in the study area. Other sedimentary basins, where this signature has been preserved, can be used as a reference for comparison purposes. From the studies of Mii et al. (1999), Wendt et al. (2001), Grossman et al. (2008) and Saltzman \& Thomas (2012), it appears that the $\delta 13 \mathrm{C}$ and $\delta 18 \mathrm{O}$ isotopic 
compositions of the middle Carboniferous (Visean) seawater are around or higher than $\mathrm{p} 2 \%$ for the $\delta 13 \mathrm{C}$ values, and range from $-4 \%$ oto $-2 \%$ for the $\delta 180$ values (see rectangles ' $a, b, c$, d' in Fig. 32). First of all, our results show that there is no correlation between $\delta 13 \mathrm{C}$ and $\delta 18 \mathrm{O}$ in our samples, as $\delta 18 \mathrm{O}$ does not show any significant variation, excluding an alteration in the marine-meteoric mixing zone (Allan \& Matthews, 1982). Our $\delta 180$ values (Fig. 9) are lower than those of typical marine ones and highly suggestive of diagenetic alteration in meteoric water. Samples display a narrow range of $\delta 18 \mathrm{O}$ and a relatively wide range of $\delta 13 \mathrm{C}$ compositions. This suggests that the middle Carboniferous samples, collected within a restricted area, were influenced in at least a single fresh water system during deposition, as highlighted by small-scale vadose vugs cemented by diagenetic equant calcite cements (Allan \& Matthews, 1982). Depleted 180 values by several per mil can also arise from burial diagenesis. But it can be excluded here as equant cementation processes occurred early, as exemplified by the preserved former dissolved fenestrae and vugs with their small-scale gravitational cements. Compaction is also very limited with rare grain contacts. Stylolites are also not well developed. As noted previously, the Castlemartin area was never covered by thick post-Visean sediments, so deep burial diagenetic effectscan be excluded in the Pembroke Limestone Group.

Table 2. Compared petrographic, calcimetric, mineralogical and sedimentological characteristics in sites A, B and D

\begin{tabular}{|c|c|c|c|}
\hline & Site A & Site B & Site D \\
\hline \multicolumn{4}{|l|}{ Sedimentary features } \\
\hline Mosaic facies lamination & PVA (but not in 1528) & PVA & VABR \\
\hline \multicolumn{4}{|l|}{ Petrography } \\
\hline \multicolumn{4}{|l|}{ Calcimetry } \\
\hline Solid rock weathered rock laminae & $-76 \% 11$ to $64 \%$ & $>98 \%-4$ to $61 \%$ & $>96 \% 19$ to $94 \% 3.5 \%$ \\
\hline PSD & Silt dominant Fine sand $\mathrm{A}$ & Silt dominant & Silt dominant \\
\hline X-ray illite/mica & VA & $P$ & VA \\
\hline X-ray kaolinite & $\mathrm{R}$ & - & P sometimes $\mathrm{A}$ \\
\hline X-ray other minerals & Corresnsite $\mathrm{P}$ in one sample & Akaganéite (1553) & - \\
\hline Quartz euhedral & A or VA & VA & not observed \\
\hline Quartz rounded & - & $\mathrm{P}$ in two samples & - \\
\hline Gypsum rosettes & $P$ in 1528 & - & - \\
\hline Gypsum laths, fibrous & P, sometimes VA $(1532,1512)$ & $A$ or VA & - \\
\hline Anhydrite (pseudomorphs?) & - & $\mathrm{P}$ in BB34 & - \\
\hline Halite pseudomorphs after gypsum & VA in $1531 \mathrm{P}$ ? in 1512 & - & - \\
\hline Goethite & $\mathrm{P}$ or $\mathrm{A}$ & A or VA & P sometimes $\mathrm{A}$ \\
\hline Goethite/manganese nodules & P or A sometimes VA & A or VA (1550) & $\mathrm{R} / \mathrm{P}$ \\
\hline Pyrite & no & no & P/A in BB11-10, BB11-05, BB11-06, BB11-10 \\
\hline Apatite & PA in 1528 & - & - \\
\hline Dolmite & - & $\mathrm{P}$ in 1512 & $A$ in BB11-10, $P$ in BB11-04 \\
\hline Organic matter & - & P somtimes $\mathrm{A}$ & \\
\hline Vadose cements & - & - & $\mathrm{P}$ in BB11-06 \\
\hline Fenestrae & $A(1512)$ & A (BB39) & $\mathrm{P}$ in BB11-05 and BB2 \\
\hline Rhizocretions, burrows, roots & $\mathrm{P}$ or $\mathrm{A}(1512)$ & A & $\mathrm{P}$ in BB11-05 and BB2 \\
\hline Pedogenesis, bioturbation and shrinkage cracks & $\mathrm{P}$ or $\mathrm{A}(1512)$ & - & P (BB11-04) \\
\hline Algal and microbial mats & - & $\mathrm{P}$ or $\mathrm{A}$ ? & - \\
\hline
\end{tabular}

Fig. 31. (Colour online) SEM photomicrographs of sample BB44: (a) rounded quartz grains with smooth surface, (b) v-shaped shock marks and (c) conchoidal fracture. 


\begin{tabular}{|c|c|c|c|c|}
\hline Sample & Site & $\delta 180 \%$ & $\delta 13 C \%$ & Petrography \\
\hline BB11-03 & $\mathrm{D}$ & -4.92 & 1.75 & Packstone with pitted/coated crinoids \\
\hline BB11-05 & $\mathrm{D}$ & -5.81 & 1.47 & Fenestral sparmicritized mudstone \\
\hline BB11-06 & $\mathrm{D}$ & -6.16 & 1.32 & Packstone/grainstone, meniscus cement (beachrock) \\
\hline BB51 & $\mathrm{D}$ & -5.00 & 0.46 & Crinoidal mudstone/wackestones, rare mudcracks \\
\hline BB2 & $\mathrm{D}$ & -5.95 & 0.31 & Sparmicritized alveolar and vuggy mudstone \\
\hline BB11-04 & $\mathrm{D}$ & -5.23 & 0.05 & Mudstone/fine-grained microsparite, alveolar structure \\
\hline BB11-10 & $\mathrm{D}$ & -8.44 & -0.14 & Recrystallized grainstone, abundant fractures \\
\hline BB52 & $\mathrm{D}$ & -5.61 & -2.13 & Peloidal fenestral microsparite \\
\hline 1512 & A & -4.87 & 0.84 & Micropeloidal microsparitic, abundant mudstone, abundant mudcracks \\
\hline 1513 & A & -5.03 & 0.73 & Laminar mudstone, abundant rootlets, pisoids, gypsum (SEM) \\
\hline 1514 & A & -4.90 & 0.65 & Laminar microconglomeratic mudstone, abundant mudcracks \\
\hline BB1528-grey & A & -4.66 & 0.69 & Crinoidal packstone/grainstone \\
\hline BB1528-red & A & -5.65 & -0.58 & Clayey micro/spamicritized partly silicified mudstone \\
\hline $1528-2$ & A & -5.94 & -1.02 & Packstone with coarse-grained crinoids and clayey laminae \\
\hline BB1555 & A & -4.68 & 0.67 & Laminar limestone (no thin-section) \\
\hline BB32 & B & -4.99 & -0.22 & Crumbly yellowish/ochre material (no thin-section) \\
\hline BB33 & $\mathrm{B}$ & -5.55 & -2.01 & Yellow/reddish silty material (no thin-section) \\
\hline BB34 & B & -5.69 & -1.21 & Moderately weathered limestone (no thin-section) \\
\hline BB35 & B & -5.04 & -0.23 & Crumbly black/ochre material (no thin-section) \\
\hline BB38 & B & -5.65 & -1.35 & Loose laminated material (no thin-section) \\
\hline BB39-hard & B & -6.08 & -1.62 & Sparmicritized mudstone with vuggy cavities (blocky/equant cements) \\
\hline BB39-altered & B & -5.74 & -1.77 & Weathered limestone \\
\hline 1554 & B & -5.90 & -1.60 & Micro/sparmicritized fenestral packstone, micritized grains, gypsum \\
\hline 1521 & B & -5.70 & -1.80 & Sparmicritized mudstone, abundant $\mathrm{mm}$-cm calcitic crystals \\
\hline BB43 & B & -5.98 & -2.04 & Laminar bioclastic intaclastic sparmicritized packstone \\
\hline BB11-11 & $\mathrm{C}$ & -4.76 & -0.68 & Mudstone/fine-grained microsparite mudstone, rare bioclasts \\
\hline 1502 & $\mathrm{C}$ & -5.27 & -0.85 & No thin-section \\
\hline 1507 & $\mathrm{C}$ & -5.23 & -1.24 & No thin-section \\
\hline 1505 & C & -5.42 & -1.31 & No thin-section \\
\hline 1503 & C & -5.46 & -1.45 & No thin-section \\
\hline BB11-02 & $\mathrm{F}$ & -4.71 & 1.25 & Coarse-grained bioclastic (crinoids, molluscs) packstone \\
\hline BB11-01 & $\mathrm{F}$ & -5.51 & -1.93 & Peloidal microsparitic laminar silty mudstone \\
\hline
\end{tabular}

(a)

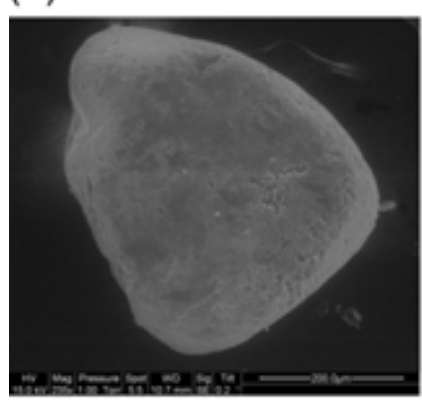

(b)

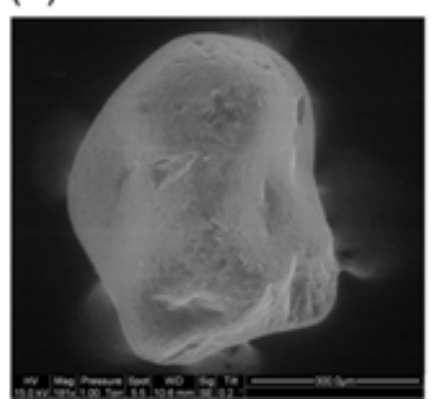

(c)

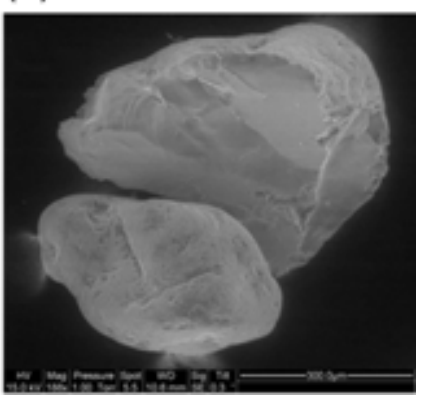

Fig. 31. (Colour online) SEM photomicrographs of sample BB44: (a) rounded quartz grains with smooth surface, (b) v-shaped shock marks and (c) conchoidal fracture.

Our $\delta 13 \mathrm{C}$ values are systematically slightly lower relative to the middle Carboniferous seawater values. These anomalously low $\delta 13 \mathrm{C}$ values are consistent with the hypothesized diagenesis mentioned above. The depletion 
in 13C is explained by shallow vadose sedimentary environments (Land, 1989; Knauth \& Kennedy, 2009; Sial et al. 2015): soil-gas CO2, which derived from oxidation of organic matter, produced depleted $\delta 13 \mathrm{C}$. The scatter plot of the variation of our $\delta 13 \mathrm{C}$ and $\delta 18 \mathrm{O}$ values (Fig. 32), with highly variable carbon isotopic compositions and nearly invariant oxygen ones, typically has the form of the 'inverted J' curve established by Lohmann (1982, 1988) for an idealized meteoric diagenetic system. The final isotopic composition after diagenesis depends upon the isotopic composition of the initial carbonate (here open marine), the composition of the diagenetic fluids (related to the degree of organic matter oxidation and organic productivity) and the degree of exchange.

The wide variability in our $\delta 13 \mathrm{C}$ compositions and narrow variability in $\delta 18 \mathrm{O}$ compositions has been documented in many limestones formations; for instance, the Holocene and upper Pleistocene of Barbados, the Lower Cretaceous Glen Rose Formation, the Pennsylvanian Strawn Formation (Texas) and the Upper Mississippian Newman Limestone (Kentucky) (see review in Allan \& Matthews, 1982). It is interpreted as a distinctive feature of the subaerial diagenetic process. These formations have been altered by early freshwater diagenesis. The absence of a positive covariance between our $\delta 13 \mathrm{C}$ and $\delta 18 \mathrm{O}$ values suggests that after being deposited in shallow marine and lagoonal environments, the Castlemartin carbonates did not evolve in a marine- meteoric water mixing zone. Our interpretation of the carbon and oxygen isotope compositions of the studied area is consistent with the palaeoenvironmental reconstruction of the area. The analysis of the isotopic compositions shows that the limestones of site B have the most negative $\delta 13 \mathrm{C}$ values (up to $-2 \%$, with an enrichment of $3-4 \%$ compared to marine limestones; data from the literature, and Table 3 and Fig. 32). Their mineralogical stabilization has been completed in the deeper vadose or deep phreatic environments.

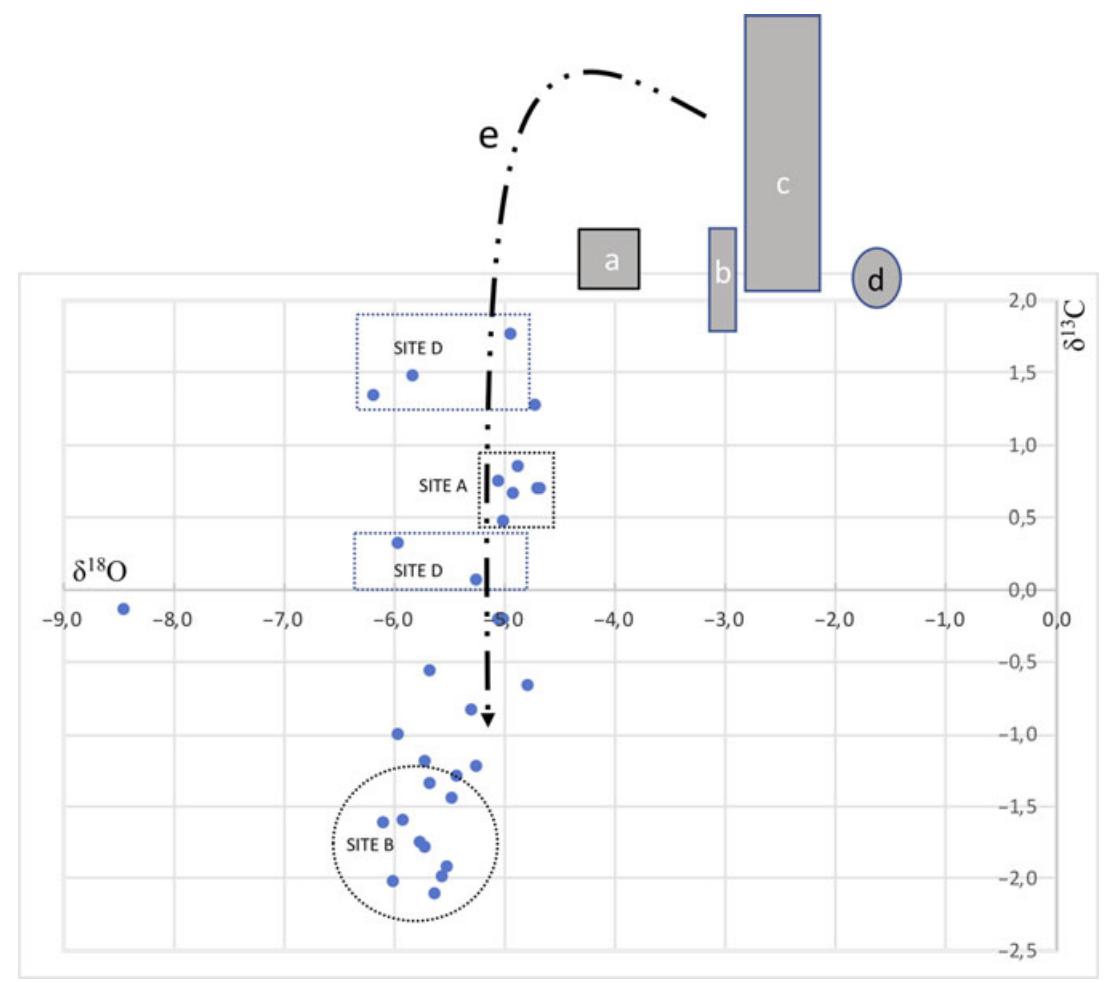

Fig. 32. (Colour online) Oxygen and carbon isotopic records. Shaded rectangles mark the suggested stable isotopic composition of Upper Visean/Serpukhovian seawater from: a - Wendt et al. (2001); b - Grossman et al. (2008); c - Mii et al. (1999); d - Saltzman \& Thomas (2012) (only isotopic carbon composition). e 'J inverted curve' of Lohmann (1982). See Table 3 for our values from 32 samples selected in Bullslaughter Bay.

\section{Discussion}

The field observations and sample analyses give preliminary results about the sedimentary conditions and early diagenetic processes in Bullslaughter Bay. The special type of isovolumetric weathering of limestones, recently described in Bullslaughter Bay (Rowberry et al. 2014), and interpreted as a 'ghost-rock' formation sensu Quinif 
(2010), has specifically attracted our attention. Our research shows that the process of alteration was complex besides the loss of calcium and lower density of the rock. On the microscopic scale, it was characterized by an intense micritization of grains and also pendant cementation in the vadose zone, where sparmicritization occurred as a result of dissolution and precipitation processes. Several diagenetic processes (such as ferruginization and de-dolomitization) have affected the sediments owing to probable variations in the meteoric fluxes, in relationship with sea-level oscillations and possible climate variability (length of the dry season).

Nowhere were karstic landforms related to an underground drainage system observed. At site A, at least one phase of emergence occurred. The superficial corrosion of the parent limestones was likely favoured by a very low $\mathrm{pH}$ in a brackish environment. It led to the development of a rocky platform with metric residual limestone blocks, which can be called 'epikarstic'. On the other hand, dolines, solution features, palaeocaves and conduits have not been observed in Bullslaughter Bay, contrary to other areas in southern Pembrokeshire and more generally in Wales (Wright, 1982a; Davies, 1991; Vanstone, 1998; Rowberry et al. 2014). The development of brackish and hypersaline conditions in Bullslaughter Bay implies a different flooding story of the Asbian/Brigantian platform to that of Gower and other South Wales areas (Wright et al. 1997). It suggests a slower flooding on flat-topped carbonate platforms, as has been recorded in the Bahamas (Rasmussen \& Neumann, 1988, 1990). Stagnant fresh water ponds could form during the sea-level rise. With strong evaporation in an arid or semi-arid climate, a phase of hypersaline bank waters could develop in supratidal and inland salt pans. This is in accordance with the meteoric signal given by the carbon and oxygen isotope compositions. Halite can also be concentrated from fresh continental waters, as in many salt lakes, or derived from the dissolution and recycling of older evaporites (Tucker, 2001; M. Al-Yousef, unpub. Ph.D. thesis, Univ. Southampton, 2003).

The noteworthy good preservation of all the features resultingfrom the diagenetic processes (such as, for example, the fragile halite pseudomorphs after gypsum) raises the question of the age of their formation. Most previous studies considered that the weathering processes necessarily occurred after the Variscan orogeny and probably during Triassic or Permian times (Thomas, 1971), if not later (Woodcock et al. 2014). In this study, all the processes could have developed very early, during or just after sedimentation. The Variscan folding of the limestone strata has not significantly deformed the loose laminae, because they were sandwiched between hard competent beds. Moreover, our analyses show the absence of compaction, on a metric as well as a micrometric scale, a result in accordance with the supposed non-deposition of thick upper and post-Carboniferous sediments in southern Pembrokeshire. The late Visean dating of the diagenetic processes results not only from our small-scale field observations and microscopic analysis, but also from the isotopic analyses, as was explained before. An interesting point, which has to be investigated in detail, is that a mixing of blocks of weathered and solid limestone is usually found in the nearby 'Gash-Breccias'. Thus, the timing of alteration is constrained, since the breccias are closely linked to the late Carboniferous - early Permian Variscan folding (Walsh et al. 2008).

A provisional interpretation of the sedimentation story proposes a complex Asbian/Brigantian sequence:

1) Marine sedimentation in shallow water, early diagenesis in the vadose or phreatic zones (site D), with possible episodic evaporate depositional conditions, as recorded by the thin palissadic veins of gypsum pseudomorphs (and also gypsum relics) in several samples from sites A and B.

(2) Phreatic meteoric environment with emergence and superficial corrosion, leading to the construction of an epikarstic rocky platform with numerous residual metric blocks of solid limestone (site A).

(3) Supratidal and/or sabkha sedimentation and meteoric diagenesis in an arid hypersaline environment (sites A and B).

(4) Sea-level rise with shallow-water marine or supratidal brackish sedimentation (sample 1528).

Further analyses will be necessary to refine this sequence, which might be significantly different in site D and in sites 
A and B. It remains also to evaluate the role of bacteria and algal mats, which were detected in some samples but not yet investigated.

\section{Conclusion}

Despite the limited area studied, this research gives first-hand regional-scope results on the Late Mississippian sedimentary environment of southern Pembrokeshire. Multiple scientific approaches and a set of various laboratory analyses show that the limestone sedimentation occurred in a coastal infra-, interior supratidal environment. The sealevel oscillations played an important part in the changing sedimentary conditions, whereas the climate seems to have been constantly hot and seasonally contrasted. Diagenetic processes, active during or just after the deposition, in the vadose or phreatic zone, induced the development of isovolumetric weathering ('ghost-rock' formation). One unexpected result of our research brings out the importance of at least one (but probably several) period(s) of surface exposure in a hypersaline environment, as testified to by gypsum crystallization, halite pseudomorphs of gypsum, euhedral bipyramidal quartz and ferromanganese nodules present in laminated sediments. Calcretization at or near the sediment surface, in the vadose zone, was one of the most widespread diagenetic processes in Bullslaughter Bay. Isotopic composition ( $\delta 18 \mathrm{O}$ and $\delta 13 \mathrm{C}$ ) values of weathered and unweathered sediments from the bay show that all the diagenetic processes took place in a meteoric environment, during or very soon after sedimentation. Field observations, petrographic and mineralogical analyses agree with a Late Mississippian dating of the sedimentary features observed in Bullslaughter Bay. Further research is needed in other places in southern Pembrokeshire to refine the regional sedimentary sequence and explain the 'Gash- Breccias' formation.

Acknowledgements. Although the authors personally assume the ideas developedin this paper, they know what they owe to all those who helped them during the research process. YBQ is particularly indebted to Peter Walsh and Matt Rowberry for the fruitful discussions they had in the field, and their decisive help to get and carry the samples. Without both of them nothing would have been possible. It is our pleasure and duty to thank all the technical team at the CNRS Laboratory of Oceanology and Geosciences (LOG) of the University of Lille (France): Sandra Ventalon (microscopy and Raman spectroscopy), Marion Delattre (calcimetry), Romain Abraham (PSD), Cindy Maliverney (thinsections) and also Denis Marin (CNRS-ULCO University at Dunkerque) who designed the map in Figure 3. We gratefully acknowledge Lenka Křižova' of Charles University (Czech Republic) for exoscopy of quartz. Our research has profited from informal discussions with many colleagues of the LOG research team. Lastly, we are greatly indebted to Franck Delpomdor (Illinois State Geological Survey) and a second anonymous reviewer, whose comments allowed us to significantly improve our original manuscript. This research received no specific grant from any funding agency, commercial or not-for-profit sectors. All the field pictures were taken by Yvonne Battiau- Queney, unless otherwise indicated. All the SEM micrographs were taken by Philippe Recourt.

\section{References}

Albright J L and LuethVW(2003) Pecos diamonds-quartz and dolomite crystals from the Seven Rivers Formation outcrops of southeastern New Mexico. New Mexico Geology 25, 63-72.

Allan JR and Matthews RK (1982) Isotope signatures associated with early meteoric diagenesis. Sedimentology 29, $797-817$. Armenteros I (2010) Diagenesis of carbonates in continental settings. In Carbonates in Continental Settings, Geochemistry, Diagenesis and Applications (eds AM Alonso-Zarza and LH Tanner), pp. 61-151. Developments in Sedimentology Vol. 62. Amsterdam: Elsevier.

Battiau-Queney Y (1980) Contribution à l'étude géomorphologique du Massif Gallois (G.B.). Thèse Doctorat ès Lettres, Honoré Champion, Paris, 798 pp. Published thesis. 
Battiau-Queney Y (1984) The pre-glacial evolution of Wales. Earth Surface Processes and Landforms 9, $229-52$.

Bibi I, Singh B and Sivester E (2011) Akaganéite ( $\beta$-FeOOH) precipitation in inland acid sulfate soils of south-western New South Wales (NSW), Australia. Geochimica et Cosmochimica Acta 75, 6429-38.

Błażejowski B and Walsh PT (2013) A Visean (Brigantian) conodont assemblage preserved in the dissolution residue of a breccia matrix at Bullslaughter Bay, Pembrokeshire, South Wales. Neues Jahrbuch für Geologie und Paläontologie 267, $239-54$.

British Geological Survey (1977) Geological Map of Pembroke and Linney Head. 1:50,000 Series. Keyworth: British Geological Survey. British Geological Survey (1996) Tectonic Map of Britain, Ireland, and Adjacent Areas. Keyworth: British Geological Survey.

Carew JL and Mylroie JE (1997) Geology of the Bahamas. In Geology and Hydrogeology of Carbonate Islands (eds HL Vacher and T Quinn), pp. 91-139. Developments in Sedimentology Vol. 54. Amsterdam: Elsevier.

Davies JR (1984) Sedimentary cyclicity in the late Asbian and early Brigantian (Dinantian) limestones of the Anglesey and Llandudno district, North Wales. Proceedings of the Geologists' Association 95, 392-3.

Davies JR (1991) Karstification and pedogenesis on a late Dinantian carbonate platform, Anglesey, North Wales. Proceedings of the Yorkshire Geological Society 48, 297-321

Davies S (2008) The record of Carboniferous sea level change in low latitude sedimentary successions from Britain and Ireland during the onset of the Late Palaeozoic ice age. In Resolving the Late Palaeozoic Ice Age in Time and Space (eds CR Fielding, TD Frank and JL Isabell), pp. 187-204. Geological Society of America, Special Paper no. 441.

Dixon EEL (1921) The Geology of the South Wales Coalfield, Part XIII: The Country Around Pembroke and Tenby. Memoirs of the Geological Survey of Great Britain. London: HMSO

Dunning FW (1992) Structure. In Geology of England and Wales (eds PMcLD Duff and AJ Smith), pp. 523-61. London, Bath: The Geological Society of London.

Falcon-Lang HJ (1999) The Early Carboniferous (Asbian-Brigantian) seasonal tropical climate of northern Britain. Palaios 14, 11626.

Fielding CR, Frank TD and Isbell JL (2008) The late Palaeozoic ice age - a review of current understanding and synthesis of global climate patterns. In Resolving the Late Paleozoic Ice Age in Time and Space (edsCR

Fielding, TD Frank andJL Isbell), pp. 343-54. Geological Society of America, Special Paper no. 441.

Flügel E (2004) Microfacies of Carbonate Rocks: Analysis, Interpretation and Application. Berlin: Springer Verlag, 976 pp.

Friedman GM and Shukla V (1980) Significance of authigenic quartz euhedra after sulfates: example from the Lockport Formation (Middle Silurian) of New York. Journal of Sedimentary Geology 50, 1299-304.

George TN (1958) Lower Carboniferous palaeogeography of the British Isles. Proceedings of the Yorkshire Geological Society 31, $227-318$.

George TN (1970) South Wales: British Regional Geology. London: HMSO, 152 pp.

George TN (1974) Lower Carboniferous rocks in Wales. In The Upper Palaeozoic and Post-Palaeozoic Rocks of Wales (ed. TR Owen), pp. 85-115. Cardiff: University of Wales Press.

George TN(1979) Eustasy and tectonics: sedimentary rhythms and stratigraphical units in British Dinantian correlation. Proceedings of the Yorkshire Geological Society 42, 229-62.

George GT (2008) The Geology of South Wales: A Field Guide. Bearsted: Published Privately (GT George).

George TN, Johnson GAL, Mitchell M, Prentice JE, Ramsbottom WHC, Sevastopulo GD and Wilson RB (1976) A Correlation of Dinantian Rocks in the British Isles. Geological Society of London, Special Report no. 7, 87 pp.

Grimm WD (1962) Idiomorphe quarze als leitmineralien fur salinare fazies. Erdöl Kohle 15, 880-7.

Grossman EL, Yancey TE, Jones TE, Bruckschen P, Chuvashov B, Mazzullo SJ and Mii HS (2008) Glaciation, aridification, and carbon sequestration in the Permo-Carboniferous: the isotopic record from low latitudes? Palaeogeography, Palaeoclimatology, Palaeoecology 268, 222-33.

Gundu Rao C (1986) Authigenic quartz and vanished evaporitic nodules in KrolDunit of Garhwal lesser Himalaya: further evidence of an extinct hypersaline environment. Current Science 57, 856-7.

Hardie LA (1977) Sedimentation on the Modern Carbonate Tidal Flats of Northwest Andros Island, Bahamas. The John Hopkins University Studies in Geology 22. Baltimore: Johns Hopkins University Press, 202 pp.

Horbury AD (1989) The relative roles of tectonism and eustasy in the deposition of the Urswick Limestone in south Cumbria and 
north Lancashire. In The Role of Tectonics in Devonian and Carboniferous Sedimentation in the British Isles (eds RS Arthurton, P Guteridge and SC Nolan), pp. 153-69. Occasional Publication of the Yorkshire Geological Society no. 6.

Hovorka S (1992) Halite pseudomorphs after gypsum in bedded anhydrite - clue to gypsum-anhydrite relationships. Journal of Sedimentary Petrology 62, 1098-111.

Isbell JL, Miller MF, Wolfe KL and Lenaker PA (2003) Timing of late Palaeozoic glaciation in Gondwana: was glaciation responsible for the development of Northern Hemisphere cyclothems? In Extreme Depositional Environments: Mega End Members in Geologic Time (edsMA Chan and AWArcher), pp. 5-24. Geological Society of America, Special Paper no. 370.

James NP and Choquette PW (1990) Limestones - the meteoric diagenetic environment. In Diagenesis (eds IA Mclleath and DW Morrow), pp. 35-74. Geoscience Canada, Reprint Series 4. Ottawa: Geological Association of Canada.

Jones DJ (1974) The Namurian series in South Wales. In The Upper Palaeozoic and Post-Palaeozoic Rocks of Wales (ed. R Owen), pp. 117-32. Cardiff: University of Wales Press.

Kahle CF (1977) Origin of subaerial Holocene calcareous crusts: role of algae, fungi and sparmicritization. Sedimentology 24, 41335.

Kelling G (1974) Upper Carboniferous sedimentation in South Wales. In The Upper Palaeozoic and Post-Palaeozoic Rocks of Wales (ed. R Owen), pp. 185-224. Cardiff: University of Wales Press.

Kelling G and Collinson JD (1992) Silesian. In Geology of England and Wales (eds PMcLD Duff and AJ Smith), pp. $239-73$. London, Bath: The Geological Society of London.

Knauth LP and Kennedy MJ (2009) The Late Precambrian greening of the Earth. Nature 460, 728-32.

Krinsley DH and Doornkamp JC (1973) Atlas of Quartz Sand Surface Textures. Cambridge: Cambridge University Press, 91 pp.

Land LS (1989) Introduction to diagenesis in the meteoric environment. In Carbonate Diagenesis and Porosity (ed. CH Moore), pp. 161-75. New York: Elsevier Science.

Leeder MR (1992) Dinantian. In Geology of England and Wales (eds PMcLD Duff and AJ Smith), pp. 207-38. London, Bath: The Geological Society of London.

Le Ribault L (1975) L'exoscopie des Quartz. Paris: Masson, 150 pp.

Leveridge BE and Hartley AJ (2006) The Variscan Orogeny: the development and deformation of Devonian/Carboniferous basins in SW England and South Wales. In The Geology of England and Wales (eds PJ Brenchley and PF Rawson), pp. 225-55. London: Geological Society of London.

Logan BW (1987) The MacLeod Evaporite Basin, Western Australia. American Association of Petroleum Geologists, Memoir no. 44, $140 \mathrm{pp}$.

Lohmann KC (1982) Inverted J carbon and oxygen isotopic trends criteria for shallow meteoric phreatic diagenesis. Geological Society of America, Abstracts with Program, 548.

Lohmann KC (1988) Geochemical patterns of meteoric diagenetic system and their application to studies of palaeokarst. In Paleokarsts (eds NP James and PW Choquette), pp. 58-80. New York: Springer Verlag.

Mii HS, Grossman EL and Yancey TE (1999) Carboniferous isotope stratigraphies of North America: implications for Carboniferous paleoceanography and Mississippian glaciation. Geological Society of America Bulletin 111, 960-73.

Moore CHS (1989) Carbonate Diagenesis and Porosity. Developments in Sedimentology Vol. 46. Amsterdam: Elsevier, 338 pp.

Owen TR (1974) The Variscan orogeny in Wales. In The Upper Palaeozoic and Post-Palaeozoic rocks of Wales (ed TR Owen), pp. 285-94. Cardiff: University of Wales Press.

PaszkowskiMand Szydłak T (1986) Evidence of hypersaline sedimentary environment in Dinantian carbonate deposits in area of Krzeszowice near Krak'ow. Annales Societatis Geologorum Poloniae 56, 385-97.

Quinif Y (2010) Fantômes de Roche et Fantômisation - Essai sur un Nouveau Paradigme en Karstogenèse. Karstologia Mémoires $18,184 \mathrm{pp}$.

Ramsbottom WHC (1973) Transgressions and regressions in the Dinantian: a new synthesis of British Dinantian stratigraphy. Proceedings of the Yorkshire Geological Society 39, 567-607.

Ramsbottom WHC (1977) Major cycles of transgression and regression (mesothems) in the Namurian. Proceedings of the Yorkshire Geological Society 41, 261-91.

Rasmussen KA and Neumann AC (1988) Holocene overprints of Pleistocene paleokarsts: Bight of Abaco, Bahamas. In Paleokarsts (eds NP James and PW Choquette), pp. 133-48. New York: Springer Verlag. 
Rasmussen K and Neumann AC (1990) Carbonate sequence development and the taphonomy of sub-karstic basin; Bight of Abaco, Bahamas. In $13^{\text {th }}$ International Sedimentology Congress, Nottingham, England, 26-31 August 1990. Abstract Volume, pp. 44950.

Rowberry MD, Battiau-Queney Y, Walsh PT, Błażejowski B, Bout-Roumazeilles V, Trentesaux A, Křrižová L and Griffiths H (2014) The weathered Carboniferous limestone at Bullslaughter Bay, South Wales: the first example of ghost-rock recorded in the British Isles. Geologica Belgica 17, 33-42.

Rygel M, Fielding C, Frank T and Birgenheier L (2008) The magnitude of late Paleozoic glacioeustatic fluctuations: a synthesis. Journal of Sedimentary Research 78, 500-11.

Sadio S (1991) Pédogenèse et Potentialités Forestières des Sols Sulfatés Acides Salés des Tannes du Sine Saloum, Sénégal. Paris: ORSTOM, $270 \mathrm{pp}$.

Saltzman MR and Thomas E (2012) Carbon isotope stratigraphy. In The Geologic Time Scale, Vol. 1 (eds FM Gradstein, JG Ogg, MD Schmitz and GM Ogg), pp. 207-32. Amsterdam: Elsevier.

Sanz A, Garcia-González MT, Vizcayno C and Rodriguez R (1996) Ironmanganese nodules in a semi-arid environment. Australian Journal of Soil Research 34, 623-34.

Schreiber BC and El-Tabakh M (2010) Deposition and early alteration of evaporites. Sedimentology 47, 215-38.

Schreiber BC and Walker D (1992) Halite pseudomorphs after gypsum: a suggested mechanism, Journal of Sedimentary Petrology $62,61-70$.

Sial AN, Gaucher C, Ferreira VP, Pereira NS, Cezario WS, Chiglino L and Lima HM (2015) Isotope and elemental chemostratigraphy. In Chemostratigraphy: Concepts, Techniques, and Applications (ed. M Ramkumar), pp. 23-64. Amsterdam: Elsevier.

Smith L and Read J (2000) Rapid onset of late Paleozoic glaciation on Gondwana. Geology 28, 279-82.

Somerville ID (1979) A cyclicity in the early Brigantian (D2) limestones east of the Clwydian Range, North Wales and its use in correlation. Geological Journal 14, 69-86.

Somerville HEA and Somerville ID (1998) Late Viséan conodont biostratigraphy and biofacies in the Kingscourt area, Ireland. Bollettino della Societa Paleontologica Italiana 37, 443-64.

Tanner LH (2010) Continental carbonates as indicator of paleoclimate. In Carbonates in Continental Settings, Geochemistry, Diagenesis and Applications (eds AM Alonso-Zarza and LH Tanner), pp. 179-214. Developments in Sedimentology Vol. 62. Amsterdam: Elsevier.

Thomas TM (1971) Gash-breccias of south Pembrokeshire: fossil karstic phenomena? Transactions of the Institute of British Geographers 54, 89-100.

Tucker ME (2001) Sedimentology Petrology, 3rd ed. Oxford: Wiley-Blackwell, 262 pp.

Ulmer-Scholle DS, Scholle PA and Brady PV (1993) Silicification of evaporates in Permian (Guadalupian) back-reef carbonates of the Delaware Basin, west Texas and New Mexico. Journal of Sedimentary Petrology 63, 955-65.

Vanstone SD (1996) The influence of climatic change on exposure surface development: a case study from the Late Dinantian of England and Wales. In Recent Advances in Lower Carboniferous Geology (eds P Strogen, ID Somerville and GL Jones), pp. 281-301. Geological Society of London, Special Publication no. 107.

Vanstone SD (1998) Late Dinantian palaeokarst of England and Wales: implications for exposure surface development. Sedimentology 45, 19-37.

Viczian I (1992) Diagenetic neoformation in Middle Triassic evaporitic and carbonate rocks, Mecsek Mts (S. Hungary). Acta Mineralogica-Petrographica, Szeged 33, 13-24.

Walkden GM(1972) The mineralogy and origin of interbedded clay wayboards in the Carboniferous of the Derbyshire Dome. Geological Journal 8, 143-60.

Walkden GM (1974) Palaeokarstic surfaces in Upper Visean (Carboniferous) limestones of the Derbyshire Block, England. Journal of Sedimentary Petrology 44, 1232-47.

Walkden GM (1987) Sedimentary and diagenetic styles in late Dinantian Carbonates of Britain. In European Dinantian Environments (eds J Miller, AE Adams. and VP Wright), pp. 131-56. Chichester: Wiley.

WalkdenGMand Davies J (1983) Polyphase erosion of subaerial omission surfaces in the Late Dinantian of Anglesey, North Wales. Sedimentology $30,861-78$. 
Walsh PT, Battiau-Queney Y, Howells SE, Ollier CD and Rowberry MD (2008) The Gash Breccias of the Pembroke Peninsula, SW Wales. Geology Today 24, 137-45.

Wanless HR and Shepard FP (1936) Sea level and climatic changes related to late Paleozoic cycles. Geological Society of America Bulletin 47, 1177-206.

Waters CN and Davies SJ (2006) Carboniferous: extensional basins, advancing deltas and coal swamps. In The Geology of England and Wales (eds PJ Brenchley and PF Rawson), pp. 173-223. London: Geological Society of London.

Waters CN, Waters RA, Barclay WJ and Davies JR (2009) A lithostratigraphical framework for the Carboniferous successions of southern Great Britain (onshore). British Geological Survey Research Report, RR/09/01.

Wendt J, Kaufmann B and Belka Z (2001) An exhumed Paleozoic underwater scenery: the Visean mud mounds of the eastern AntiAtlas (Morocco). Sedimentary Geology 145, 215-33.

Woodcock NH, Miller AVM and Woodhouse CD (2014) Chaotic breccia zones on the Pembroke Peninsula, South Wales: evidence for collapse into voids along dilatational faults. Journal of Structural Geology 69, 91-107.

Wright VP (1982a) The recognition and interpretation of palaeokarst: two examples from the Lower Carboniferous of South Wales. Journal of Sedimentary Petrology 52, 83-94.

Wright VP (1982b) Calcrete palaeosols from the Lower Carboniferous Llanelly Formation, South Wales. Sedimentary Geology 33 , $1-33$.

Wright VP and Tucker ME (1991) Calcretes: an introduction. In Calcretes (eds VP Wright and ME Tucker), pp. 1-22. International Association of Sedimentologists, Reprint Series 2. Oxford: Blackwell Scientific Publications.

Wright VP and Vanstone SD (2001) Onset of late Palaeozoic glacio-eustasy and the evolving climates of low latitude areas: a synthesis of current understanding. Journal of the Geological Society, London 158, 579-82.

Wright VP, Vanstone SD and Marshall JD (1997) Contrasting flooding histories of Mississippian carbonate platforms revealed by marine alteration in palaeosols. Sedimentology $44,825-42$. 